\title{
Treating Rett syndrome: from mouse models to human therapies
}

\author{
Neeti Vashi ${ }^{1,2} \cdot$ Monica J. Justice ${ }^{1,2}$ \\ Received: 7 January 2019 / Accepted: 9 February 2019 / Published online: 28 February 2019 \\ (c) Springer Science+Business Media, LLC, part of Springer Nature 2019
}

\begin{abstract}
Rare diseases are very difficult to study mechanistically and to develop therapies for because of the scarcity of patients. Here, the rare neuro-metabolic disorder Rett syndrome (RTT) is discussed as a prototype for precision medicine, demonstrating how mouse models have led to an understanding of the development of symptoms. RTT is caused by mutations in the X-linked gene methyl-CpG-binding protein 2 (MECP2). Mecp2-mutant mice are being used in preclinical studies that target the $M E C P 2$ gene directly, or its downstream pathways. Importantly, this work may improve the health of RTT patients. Clinical presentation may vary widely among individuals based on their mutation, but also because of the degree of X chromosome inactivation and the presence of modifier genes. Because it is a complex disorder involving many organ systems, it is likely that recovery of RTT patients will involve a combination of treatments. Precision medicine is warranted to provide the best efficacy to individually treat RTT patients.
\end{abstract}

\section{Understanding and developing therapies for rare disorders}

Rett syndrome (RTT) is a rare disorder that occurs in 1 in 10,000 females (Rett 1966; Haas 1988). It is characterized by seemingly normal neurological and physical development during the early postnatal period, followed by symptom manifestation between 6 and 18 months of age (Hagberg 2002). Symptoms progress over several stages (Table 1): stagnation, rapid regression, plateau, and late motor deterioration. The stagnation stage is characterized by subtle developmental delays in motor and language skills, and possible decreased alertness. This stage is often overlooked and leads to a delayed diagnosis, as parents and doctors may not notice these subtle changes. During the rapid regression stage, the child loses purposeful hand skills and spoken language, experiences motor impairments, and develops breathing abnormalities. Children may develop autistic-like features such as loss of interest in social interaction, and seizures may occur. This is followed by the plateau stage, during

Monica J. Justice

monica.justice@sickkids.ca

1 Genetics and Genome Biology Program, The Hospital for Sick Children, The Peter Gilgan Centre for Research and Learning, Toronto, ON M5G 0A4, Canada

2 Department of Molecular Genetics, University of Toronto, Toronto, ON M5S 1A1, Canada which motor problems and seizures become more common, but communication skills may improve. Lastly, children enter the late motor deterioration stage during which severe physical disability is common, and many patients become wheelchair dependent.

Independent of disease stage, subsets of patients also experience gastrointestinal problems (Motil et al. 2012), abnormal cardiorespiratory coupling (Kumar et al. 2017), decreased bone density (Shapiro et al. 2010), early-onset osteoporosis (Haas et al. 1997), bruxism (Alpoz et al. 1999), dyslipidaemia (Justice et al. 2013; Segatto et al. 2014), inflammation of the gallbladder (Anderson et al. 2014), scoliosis (Anderson et al. 2014), urological dysfunction (Ward et al. 2016), and sleep disturbances (Young et al. 2007). Additionally, RTT patients have an increased incidence of unexpected death, and often die due to respiratory infection, cardiac instability, and respiratory failure (Laurvick et al. 2006; Anderson et al. 2014). Current treatment options are limited to symptom control.

\section{Rett syndrome is caused by mutations in methyl-CpG-binding protein 2 (MECP2)}

Although a genetic basis for RTT was hypothesized as early as 1983 based on the preferential involvement of females (Hagberg et al. 1983), it was not until 1999 that a causative gene for the disorder was identified. Using a systematic gene 
Table 1 Rett syndrome progresses over several stages

\begin{tabular}{|c|c|c|}
\hline Stage & Age & Symptoms \\
\hline 1. Stagnation & 6-18 months & $\begin{array}{l}\text { - Developmental delays (postural control, motor, language) } \\
\text { - Reduced eye contact } \\
\text { - Hand-wringing may occur } \\
\text { - Microcephaly may occur }\end{array}$ \\
\hline 2. Rapid regression & $1-4$ years & $\begin{array}{l}\text { - Loss of purposeful hand skills } \\
\text { - Stereotypical hand movements (wringing, washing, tap- } \\
\text { ping) } \\
\text { - Loss of spoken language } \\
\text { - Walking may be unsteady } \\
\text { - Breathing irregularities may occur } \\
\text { - Autistic-like features } \\
\text { - Microcephaly progression } \\
\text { - Seizures may occur }\end{array}$ \\
\hline 3. Plateau/pseudo-stationary & 2-potentially life & $\begin{array}{l}\text { - Hand apraxia/dyspraxia } \\
\text { - Motor coordination difficulties and/or loss of motor skills } \\
\text { - Improvement of communication skills may occur } \\
\text { - Seizures are common }\end{array}$ \\
\hline 4. Late motor deterioration & 10-life & $\begin{array}{l}\text { - Severe physical disability } \\
\text { - Muscle weakness, rigidity, or spasticity } \\
\text { - Wheelchair dependency may occur }\end{array}$ \\
\hline
\end{tabular}

screening approach, Amir et al. identified mutations in the gene methyl-CpG-binding protein $2(M E C P 2)$ as the cause of some cases of RTT (Amir et al. 1999). It is now known that de novo mutations in MECP2 account for $95 \%$ of typical RTT cases (Bienvenu et al. 2000). Although nearly 600 RTT-causing mutations have been identified in $M E C P 2$, only eight missense and nonsense mutations account for approximately $70 \%$ of mutations in RTT (R106W, R133C, T158M, R168X, R255X, R270X, R294X, and R306C) (Neul et al. 2008). Large deletions in MECP2 account for another $15 \%$ of RTT-causing mutations. Interestingly, additional mutations in MECP2 have been associated with autism (Xi et al. 2011), intellectual disability (Bianciardi et al. 2016), and lupus erythematosus (Liu et al. 2013).

$M E C P 2$ encodes a nuclear protein (MECP2), which is especially abundant within neurons but is expressed at varying levels in every human tissue (Lewis et al. 1992; Tate et al. 1996; Shahbazian et al. 2002b). It is comprised of four domains and is host to several posttranslational modifications (Reviewed in Kyle et al. 2018). MECP2 functions as a global transcriptional regulator by binding specifically to methylated DNA, recruiting protein partners and regulatory complexes to modify transcriptional activity (Nan et al. 1997; Chandler et al. 1999). Although MECP2 is thought to primarily repress gene transcription, its role in transcriptional activation (Chahrour et al. 2008), chromatin remodeling, and mRNA splicing has also been described (reviewed in Lyst and Bird 2015). MECP2 expression correlates with the postnatal maturation of the central nervous system (CNS) and neuronal differentiation, suggesting a role in CNS function and maintenance (Kishi and Macklis 2004).
Within the brain, $M E C P 2$ is seven times higher in neurons than in glia; however, $M E C P 2$ has important roles in glia as well (Ballas et al. 2009; Skene et al. 2010; Lioy et al. 2011).

Clinical studies have highlighted the degree of phenotypic variation in Rett syndrome patients (Fig. 1a). Genotype-phenotype correlation studies demonstrate that early truncating mutations in MECP2 (R168X, R255X, and R270X) and large INDELs cause the most severe phenotype, whereas most missense mutations (R133C and R306C) and late truncating mutations (R294X) are the mildest (Neul et al. 2008; Cuddapah et al. 2014). Thus, MECP2 mutation status is a predictor of disease severity. Despite this, phenotypic variation is also reported in familial cases of RTT where affected sisters present with the same mutation (Zhang et al. 2017); these differences may be due to differences in X chromosome inactivation (XCI). Because $M E C P 2$ is inherited on the $\mathrm{X}$ chromosome, female heterozygous RTT patients are mosaic carriers of normal and mutated $M E C P 2$. XCI is a random process by which one $\mathrm{X}$ chromosome is silenced in each cell. $\mathrm{XCI}$ can be skewed where the X chromosome carrying the mutated MECP2 is more or less expressed throughout the brain and body, influencing the clinical presentation of RTT (Fig. 1b) (Ishii et al. 2001; Knudsen et al. 2006). Tests for skewed XCI are possible in the clinic. In cases where XCI is not skewed toward one allele, phenotypic variation may be due to the presence of modifier mutations. Modifiers are genes whose function has phenotypic outcomes on the effect of another gene. Mutations in modifier genes may alleviate or enhance clinical symptoms in patients as well (Fig. 1c). 
Fig. 1 Symptom severity in RTT is influenced by mutation status, XCI pattern, and modifier genes. a Of the 8 most common RTT-causing $M E C P 2$ mutations, R133C and R306C cause the least severe clinical presentation, whereas the missense mutations R106W and $\mathrm{T} 158 \mathrm{M}$, and nonsense mutations R168X, R255X, R270X, and R294X cause the most severe phenotype. Large deletions in the MECP2 gene also cause a severe phenotype, whereas smaller C-terminal truncations are less severe. $\mathbf{b}$ Differences in XCI skewing patterns can influence clinical presentation, where patients with fewer cells expressing the mutant MECP2 gene will have less severe symptoms. c Individuals who have modifier mutations in genes that suppress the RTT phenotype have a more favorable clinical presentation than individuals with mutations in genes that enhance detrimental symptoms

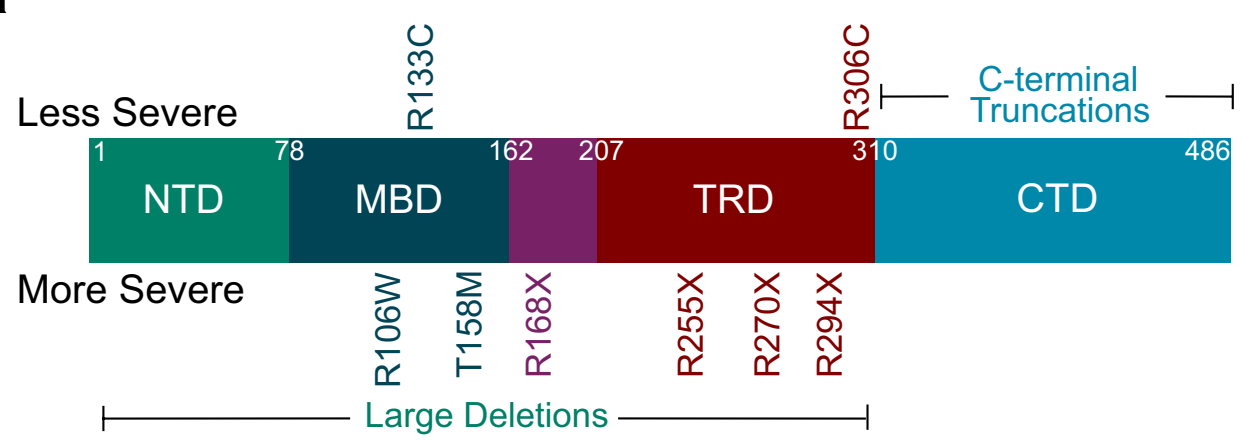

b
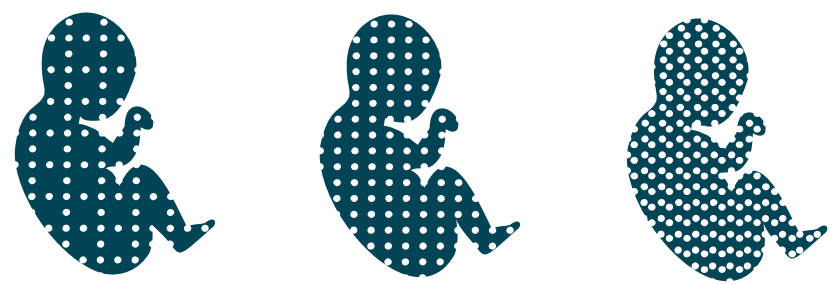

Healthy Cells Mutant Cells

\section{Mouse models recapitulate key symptoms of RTT}

Mecp2 is found in all vertebrates, but not in non-vertebrate genetic model organisms, including the fruit fly or the worm (Hendrich and Tweedie 2003). Therefore, developing mouse models of the disorder was needed for a mechanistic understanding of the onset and severity of clinical signs. Shortly after the identification of $M E C P 2$ as the causative gene in RTT, two Mecp2-null mouse models were generated, which are now the primary models used to study the disease (Table 2). The Mecp $2^{\text {tml.1Bird }}$ mouse line completely lacks $M E C P 2$ protein product (Guy et al. 2001), whereas the $M e c p 2^{\text {tml.1Jae }}$ line expresses small MECP2 protein fragments (Chen et al. 2001). However, both null models display a similar phenotype that recapitulates symptoms of RTT and both have been used extensively to study the mechanistic basis for disease.
RTT predominantly affects females, so female Mecp2mutant mice are the most clinically relevant model. However, female Mecp2-mutant mice display deviations in phenotype presentation due to XCI skewing making it difficult to discern which phenotypes arise through cell autonomous versus non-autonomous pathways. Therefore, the majority of RTT mouse studies take place in hemizygous Mecp2mutant male mice due to their consistent phenotype and their complete lack of $M E C P 2$ protein, which is advantageous for mechanistic research.

Hemizygous male Mecp2-null mice are phenotypically normal until 4 weeks of age when they develop a RTTlike phenotype consisting of hind limb clasping, tremors, breathing irregularities, loss of muscle tone, and hypoactivity (Chen et al. 2001; Guy et al. 2001). These mice also display a reduced brain weight and body weight, experience a rapid phenotypic regression, and die between 6 and 12 weeks of age. Female mice heterogeneous for Mecp 2 deletions develop the same features at 4-6 months of age and typically live a normal lifespan. 


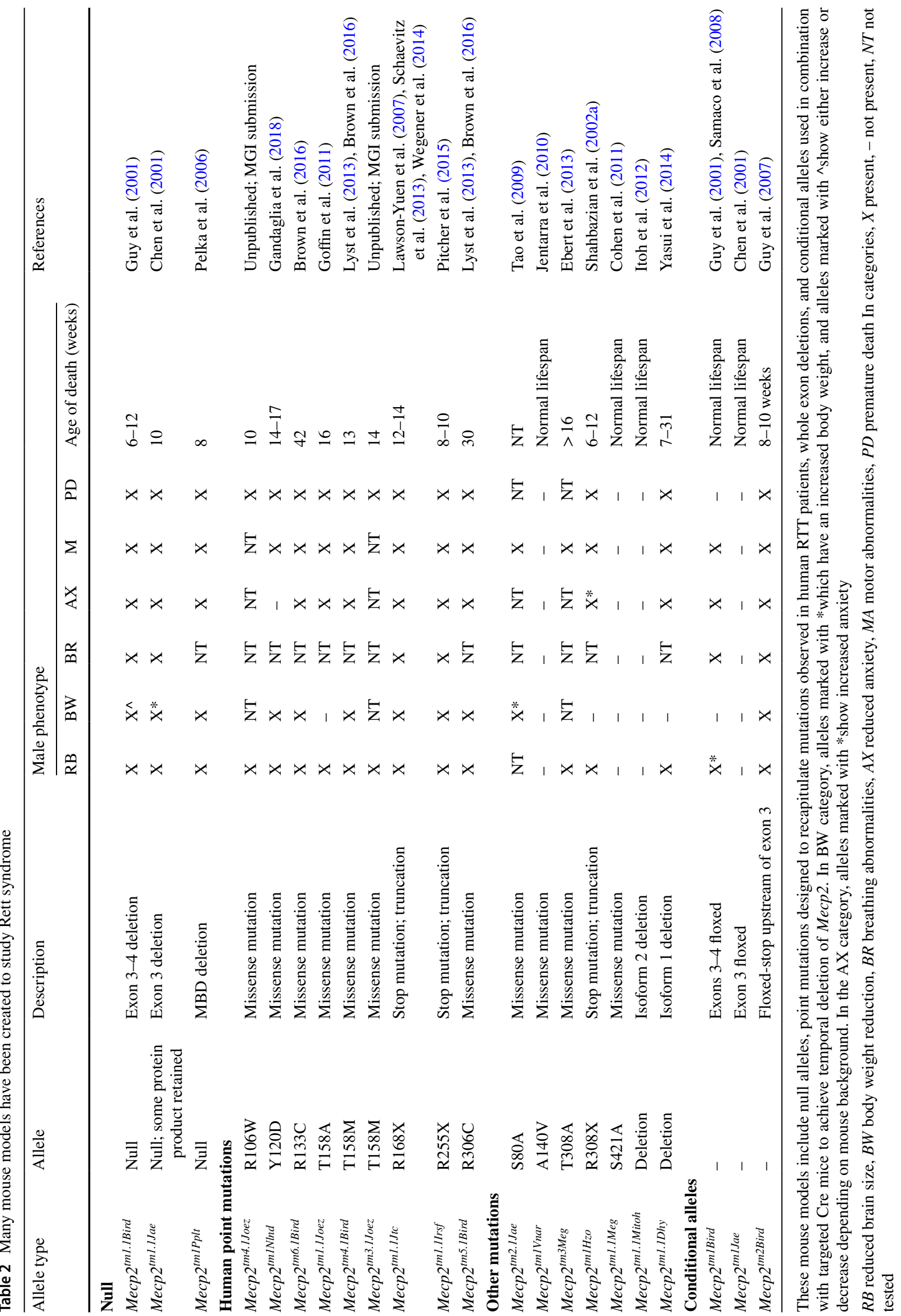




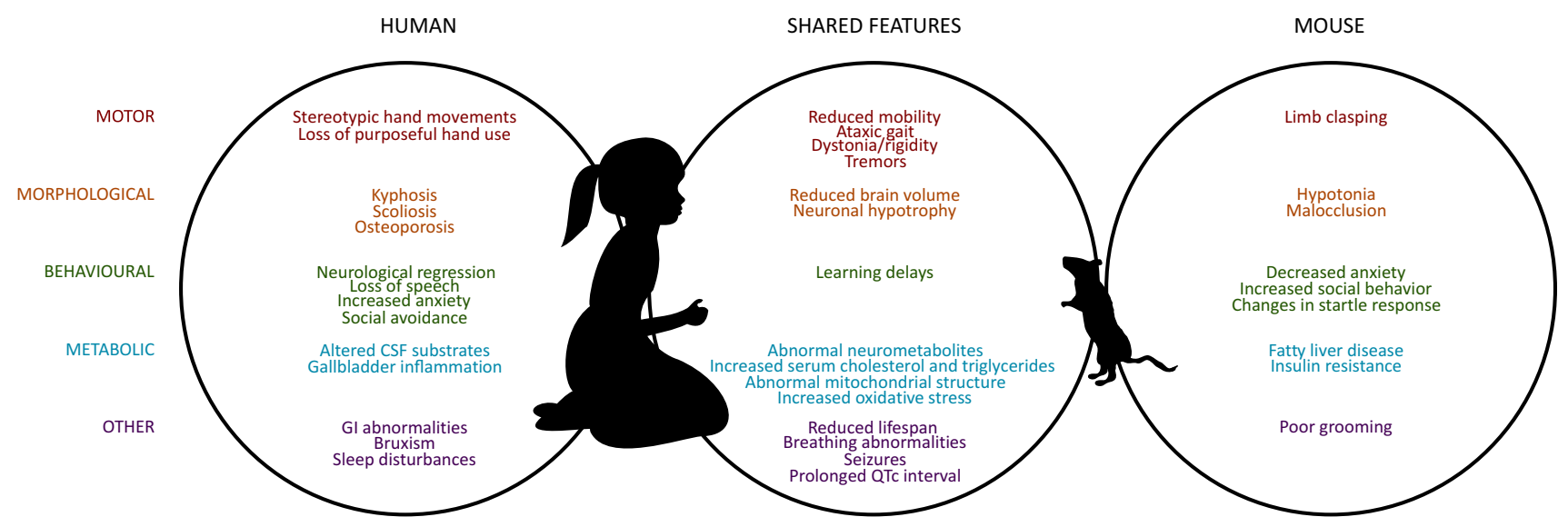

Fig. 2 RTT patients and Mecp2-mutant mouse models share many features

Mecp2-mutant mouse models recapitulate a broad spectrum of phenotypes seen in human RTT patients (Fig. 2). The most profound symptoms in human patients and most Mecp2-mutant mice are motor abnormalities, including reduced mobility, impaired motor coordination, ataxic gait, and tremors (Hagberg and Witt-Engerström 1986). While human patients replace purposeful hand use with stereotypic movements, mouse models clasp their hindlimbs (Chen et al. 2001; Guy et al. 2001); this may resemble the hallmark human symptom, but it is not a phenotype specific to RTT mouse models (Lalonde and Strazielle 2011). Morphologically, both human patients and Mecp 2 mouse models exhibit a reduced brain volume and neuronal hypotrophy (Chahrour and Zoghbi 2007). Behaviorally, RTT patients experience a neurological regression and loss of speech, two traits which cannot be measured in mouse models. However, both may experience some learning deficits (Elefant and Wigram 2005; Moretti 2006). Interestingly, while human RTT patients typically exhibit increased anxiety and social avoidance (Mount et al. 2002), Mecp2-mutant mice are less anxious and more social, as assessed by phenotypic tests available for rodents (Samaco et al. 2012; Orefice et al. 2016; Wu et al. 2016). Metabolic disturbances in both human patients and mice include abnormalities in neurometabolites (Goffin and Zhou 2012), increased serum cholesterol and triglycerides (Buchovecky et al. 2013; Justice et al. 2013; Segatto et al. 2014; Kyle et al. 2018), abnormal mitochondrial structure (Shulyakova et al. 2017), and increased oxidative stress (De Felice et al. 2009; Janc et al. 2016). Finally, both experience breathing irregularities (Ramirez et al. 2013), cardiac abnormalities (prolonged QTc intervals) (McCauley et al. 2011; Hara et al. 2015), seizures, and a shortened lifespan (Guy et al. 2001; Anderson et al. 2014). Overall, Mecp2-mutant mice exhibit a broad range of phenotypes that recapitulate symptoms of human RTT patients, making them excellent models to study the disorder.
Despite their face validity, null mouse models do not always represent human cases molecularly since many RTT patients carry missense mutations that result in a lessefficient or unstable $M E C P 2$ protein rather than a complete loss of it. To circumvent this caveat, several mouse lines with point mutations and deletions in $M E C P 2$ have been engineered to recapitulate clinically relevant mutations observed in human patients (Table 2). Of the eight most common missense mutations in RTT patients, six have an established mouse model which recapitulates symptoms of the disease. These mice have been instrumental in understanding the functional consequences of RTT-causing mutations and their correlation to symptom severity. For example, RTT patients carrying MECP2 T158M mutations display severe RTT symptoms, while motor and speech preservation is observed in patients with a R133C mutation (Cuddapah et al. 2014). Consistently, male mice carrying these missense mutations have a lifespan of 13 weeks and 42 weeks, respectively. Functional studies in mice determined that while both the $\mathrm{T} 158 \mathrm{M}$ and $\mathrm{R} 133 \mathrm{C}$ mutations create $M E C P 2$ proteins with reduced DNA-binding ability, the T158M mutation also leads to protein instability, likely resulting in the unique and more severe phenotype presentation (Brown et al. 2016).

Further, mice with Mecp 2 mutations have been designed to study specific biological questions of functional relevance. For example, while $M E C P 2$ is expressed as two isoforms, their expression levels vary among tissues, with $M E C P 2$ e 1 being more abundant than e2 in the brain. Studies that deleted either MECP2_e1 or e2 throughout the body found that only deletion of $M E C P 2$ e 1 led to RTT-like phenotypes and a shortened lifespan, while deletion of e2 was required for placental development (Itoh et al. 2012; Yasui et al. 2014). Additionally, $M E C P 2$ protein is a host to numerous posttranslational modifications (PTMs), including phosphorylation at serine 80 (S80) and 421 (S421). Mutating either of these serine residues in mice prevented this 
site-dependent phosphorylation and determined that these PTMs are important for the association of MECP2 to chromatin and its role in regulating neuronal gene expression (Tao et al. 2009; Cohen et al. 2011).

Finally, conditional-ready alleles have been constructed by engineering lox $\mathrm{P}$ sites flanking a portion of the Mecp 2 gene (Floxed) (Chen et al. 2001; Guy et al. 2001). These mice can be crossed with transgenic mice carrying a tissue- or cell type-specific Cre to achieve spatial or temporal deletion of Mecp2. Studies using these mice have greatly informed Mecp2 function both within the CNS and in peripheral tissues. Neuronal dysfunction was once considered the only cause of RTT, despite MECP2's expression in glial cells. Crossing Mecp2-floxed mice to mice with a glial-specific GFAP-Cre transgene achieved targeted deletion of Mecp 2 in astrocytes. These mice developed RTTlike symptoms including decreased body weight, hindlimb clasping, and irregular breathing, demonstrating that glial Mecp2 deficiency could produce some RTT symptoms (Lioy et al. 2011). Additionally, liver-targeted deletion of Mecp 2 was achieved by crossing Mecp2-floxed mice to mice expressing Cre under the control of an Albumin promoter (Alb-Cre). The resulting mice develop fatty liver disease and dyslipidemia, implicating $M E C P 2$ in the regulation of lipid metabolism in non-CNS tissues (Kyle et al. 2016). Since transgenic mice have been engineered to express Cre from many diverse cell types, continued studies are likely to achieve a thorough understanding of Mecp2's role in a variety of tissues and cell types.

A significant question in RTT research concerns phenotypic reversibility: Since RTT patients do not display neuronal death, it is possible that Mecp2-deficient cells can be repaired. In a milestone study, a mouse model was engineered to contain a transcriptional STOP cassette flanked by loxP, which was inserted into the endogenous Mecp 2 gene (Guy et al. 2007). These 'FloxedStop' mice were crossed with mice expressing a ubiquitous Cre-ER transgene. This strategy allowed for Mecp 2 to remain silenced in mice until Cre could be activated with injection of tamoxifen. 'FloxedStop' male mice were identical to Mecp2-null mice, developed RTT-like symptoms and had a shortened lifespan. Following phenotype onset, tamoxifen was administered systemically, removing the loxP-STOP-loxP cassette and restoring Mecp 2 expression to $80 \%$ of normal levels. Remarkably, restoring $M E C P 2$ expression reversed neurological symptoms and normalized lifespan (Guy et al. 2007). This key study demonstrated that Mecp2-induced pathology is not permanent and symptom reversal may be possible in human patients.

Given MECP2's high expression levels, its global DNAbinding affinity, and its multitude of proposed binding partners and functions, it is unsurprising that Mecp2-deficiency results in a myriad of dysregulated pathways. MECP2 has been implicated in neuronal maintenance (Kishi and Macklis 2004; Guy et al. 2011), glial cell function (Ballas et al. 2009), neurotransmitter signaling (Goffin and Zhou 2012), growth factor signaling (Itoh et al. 2007), lipid metabolism (Buchovecky et al. 2013), oxidative stress (Großer et al. 2012), and more. Current preclinical research follows two approaches: targeting pathways downstream of MECP2 or directly targeting $M E C P 2$ and its protein product (Fig. 3).

\section{Using mouse models to develop therapeutics for RTT targeting pathways downstream of Mecp2}

The first approach of recognizing components that lie in pathways downstream of $M E C P 2$ has identified many targets with the potential for treatment. Pharmacological therapeutics for targets downstream of $M E C P 2$ can be repurposed to improve neurotransmitter signaling, growth factor signaling, and metabolism (Table 3). Importantly, several of these treatments ameliorated symptoms in Mecp2-mutant mice and have spawned clinical trials in patients. However, these strategies revealed several limitations. First, because the precise functions of $M E C P 2$ are still unknown, identifying the pathways it regulates, especially those which may be subtly changed in the absence of $M E C P 2$, is difficult. Another

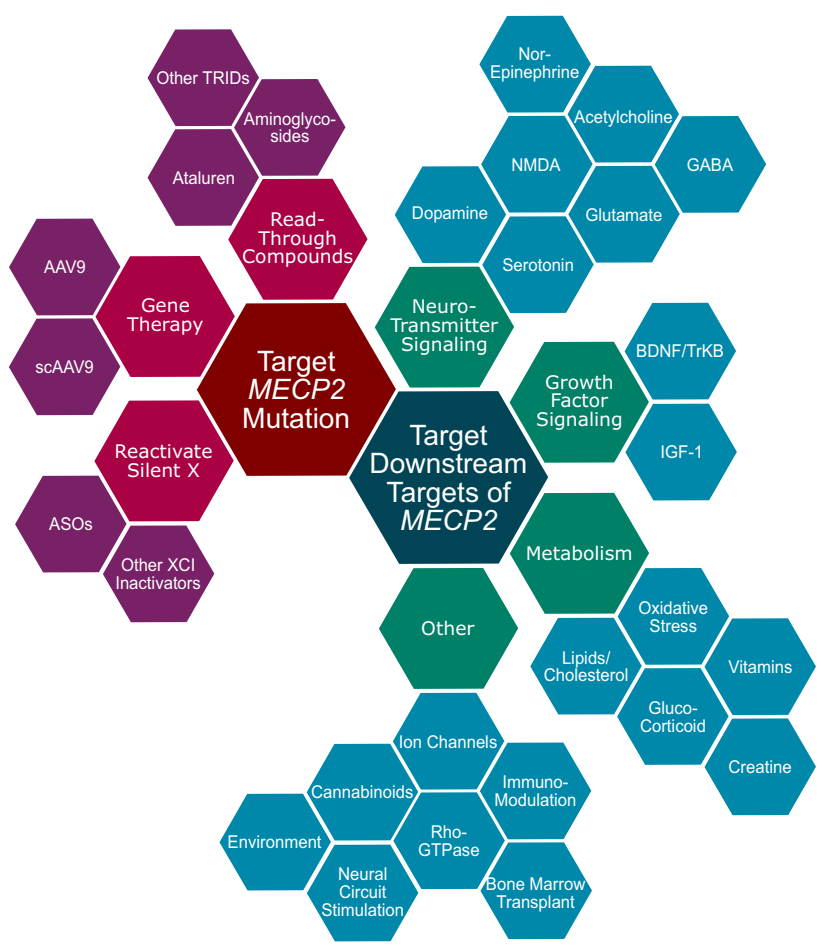

Fig. 3 Treatment options in RTT either directly target $M E C P 2$ mutation or target pathways downstream of $M E C P 2$. Treatment options are further divided within these two groups 
Table 3 Preclinical treatments targeting pathways downstream of Mecp2

\begin{tabular}{|c|c|c|c|c|c|c|}
\hline Treatment & Mechanism & Mouse model & $\begin{array}{l}\text { Prolong } \\
\text { lifespan }\end{array}$ & Improved phenotype & References & Clinical trial \\
\hline \multicolumn{7}{|c|}{ Neurotransmitter signaling } \\
\hline Citalopram & $\begin{array}{l}\text { Serotonin reuptake } \\
\text { blocker }\end{array}$ & Mecp $2^{\text {tml.1Bird }}$ & NT & $\begin{array}{l}\text { Improved sensitivity to carbon } \\
\text { dioxide exposure }\end{array}$ & Toward et al. (2013) & - \\
\hline 8-OH-DPAT & Serotonin 1a agonist & Mecp $2^{\text {tml.1Bird }}$ & NT & Reduced apneas & Abdala et al. (2010) & - \\
\hline F15599 & Serotonin 1a agonist & $\operatorname{Mecp} 2^{\text {tml.1Bird }}$ & NT & $\begin{array}{l}\text { Reduced apneas and improves } \\
\text { breathing irregularity }\end{array}$ & Levitt et al. (2013) & - \\
\hline Sarizotan & $\begin{array}{l}\text { Serotonin 1a agonist } \\
\text { \& dopamine D2-like } \\
\text { receptor }\end{array}$ & $\begin{array}{l}\text { Mecp } 2^{\text {tm1.1Bird }} \\
\text { Mecp } 2^{\text {tm1.1Jae }} \\
M e c p 2^{\text {tm1.1Jtc }}\end{array}$ & NT & $\begin{array}{l}\text { Reduced apneas and improved } \\
\text { breathing irregularity }\end{array}$ & Abdala et al. (2014) & $\mathrm{Y}$ \\
\hline LP-211 & $\begin{array}{l}\text { Serotonin } 7 \text { receptor } \\
\text { agonist }\end{array}$ & $M e c p 2^{t m 1 H z o}$ & NT & $\begin{array}{l}\text { Improved overall health, memory } \\
\text { and anxiety }\end{array}$ & $\begin{array}{l}\text { De Filippis et al. } \\
\text { (2014) }\end{array}$ & - \\
\hline Levodopa & $\begin{array}{l}\text { Dopaminergic stimula- } \\
\text { tion }\end{array}$ & Mecp $2^{\text {tml.1Bird }}$ & $\mathrm{Y}$ & Improved motor activity & Szczesna et al. (2014) & - \\
\hline Ketamine & $\begin{array}{l}\text { NMDA receptor } \\
\text { antagonist }\end{array}$ & Mecp $2^{\text {tm1.1Jae }}$ & NT & Improved startle response & Kron et al. (2012) & $\mathrm{Y}$ \\
\hline Ketamine & $\begin{array}{l}\text { NMDA receptor } \\
\text { antagonist }\end{array}$ & Mecp $2^{\text {tml.1Bird }}$ & $\mathrm{Y}$ & $\begin{array}{l}\text { Improved limb clasping, motor } \\
\text { coordination and reduced } \\
\text { apneas }\end{array}$ & Patrizi et al. (2016) & $\mathrm{Y}$ \\
\hline NO-711 & GABA reuptake blocker & Mecp $2^{\text {tm1.1Bird }}$ & NT & Reduced apneas & Abdala et al. (2010) & - \\
\hline $\begin{array}{l}\text { Benzodiazepine diaz- } \\
\text { epam }\end{array}$ & GABA reuptake blocker & Mecp $2^{\text {tm1.1Bird }}$ & NT & Reduced apneas & Abdala et al. (2010) & - \\
\hline $\mathrm{L}-838,417$ & GABA reuptake blocker & $\operatorname{Mecp} 2^{\text {tm1.1Bird }}$ & NT & Reduced apneas & (Abdala et al. 2010) & - \\
\hline Tiagabine & GABA reuptake blocker & Mecp $2^{\text {tml.1Bird }}$ & $\mathrm{Y}$ & No improvement & El-Khoury et al. (2014) & - \\
\hline THIP & GABA receptor agonist & Mecp $2^{\text {tml.1Bird }}$ & $\mathrm{Y}$ & $\begin{array}{l}\text { Improved motor function, social } \\
\text { behavior, and reduced apneas }\end{array}$ & Zhong et al. (2016) & - \\
\hline Mirtazapine & GABA release promoter & Mecp $2^{\text {tml.1Bird }}$ & NT & $\begin{array}{l}\text { Improved overall healthy, neu- } \\
\text { ronal morphology, dendritic } \\
\text { spine number, anxiety }\end{array}$ & Bittolo et al. (2016) & - \\
\hline VUO462807 & $\begin{array}{l}\mathrm{mGlu}_{5} \text { positive allosteric } \\
\text { modulator }\end{array}$ & Mecp $2^{\text {tml.1Bird }}$ & $\mathrm{N}$ & $\begin{array}{l}\text { Improved motor function and limb } \\
\text { clasping }\end{array}$ & Gogliotti et al. (2016) & - \\
\hline VU0422288 & $\begin{array}{l}\mathrm{mGlu}_{7} \text { positive allosteric } \\
\text { modulator }\end{array}$ & Mecp $2^{\text {tml.1Bird }}$ & NT & $\begin{array}{l}\text { Reduced apneas, improves learn- } \\
\text { ing and memory }\end{array}$ & Gogliotti et al. (2017) & - \\
\hline CTEP & $\begin{array}{l}\mathrm{mGluR}_{5} \text { negative allos- } \\
\text { teric modulator }\end{array}$ & Mecp $2^{\text {tml.1Bird }}$ & $\mathrm{Y}$ & $\begin{array}{l}\text { Reduced apneas, improved } \\
\text { memory }\end{array}$ & Tao et al. (2016) & - \\
\hline Acetyl-L-carnitine & Acetyl group donor & Mecp $2^{\text {tml.1Jae }}$ & NT & $\begin{array}{l}\text { Improved weight gain, motor } \\
\text { activity and memory }\end{array}$ & Schaevitz et al. (2012) & - \\
\hline Acetyl-L-carnitine & Acetyl group donor & Mecp $2^{\text {tm1.1Jae }}$ & NT & $\begin{array}{l}\text { Improved weight gain, motor } \\
\text { activity and memory }\end{array}$ & Schaevitz et al. (2012) & - \\
\hline Choline & $\mathrm{ACh}$ & Mecp $2^{\text {tm1.1Jae }}$ & NT & $\begin{array}{l}\text { Improved motor coordination and } \\
\text { activity }\end{array}$ & $\begin{array}{l}\text { Nag and Berger- } \\
\text { Sweeney (2007) }\end{array}$ & - \\
\hline Choline & $\mathrm{ACh}$ & $M e c p 2^{t m 1 H z o}$ & NT & Improved motor activity & Ricceri et al. (2011) & - \\
\hline Choline & $\mathrm{ACh}$ & Mecp $2^{\text {tml.1Bird }}$ & NT & $\begin{array}{l}\text { Improved motor coordination, } \\
\text { anxiety and social behavior }\end{array}$ & Chin et al. (2018) & - \\
\hline D-NAC & $\begin{array}{l}\text { Dendrimer-conjugated } \\
\mathrm{N} \text {-acetyl cysteine }\end{array}$ & Mecp $2^{\text {tml.1Bird }}$ & NT & $\begin{array}{l}\text { Improved overall health, limb } \\
\text { clasping }\end{array}$ & Nance et al. (2017) & - \\
\hline Desipramine & $\begin{array}{l}\text { Norepinephrine reuptake } \\
\text { inhibitor }\end{array}$ & Mecp $2^{\text {tml.1Bird }}$ & $\mathrm{Y}$ & Improved breathing irregularities & Roux et al. (2007) & $\mathrm{Y}$ \\
\hline Desipramine & $\begin{array}{l}\text { Norepinephrine reuptake } \\
\text { inhibitor }\end{array}$ & Mecp $2^{\text {tml.1Bird }}$ & $\mathrm{Y}$ & Reduced apneas & Zanella et al. (2008) & $\mathrm{Y}$ \\
\hline Clenbuterol & $\begin{array}{l}\text { B2-adrenergic receptor } \\
\text { agonist }\end{array}$ & Mecp $2^{\text {tml.1Bird }}$ & $\mathrm{Y}$ & $\begin{array}{l}\text { Improved motor coordination and } \\
\text { breathing irregularities }\end{array}$ & Mellios et al. (2014) & - \\
\hline D-cycloserine & D-alanine analog & Mecp $2^{\text {tml.1Jae }}$ & NT & No improvement & Na et al. (2017) & - \\
\hline \multicolumn{7}{|c|}{ Growth factor signaling } \\
\hline CX546 & Ampakine (BDNF) & Mecp $2^{\text {tml.1Jae }}$ & NT & Improved breathing irregularity & Ogier et al. (2007) & - \\
\hline Fingolimod & $\begin{array}{l}\text { Sphingosine-1 phosphate } \\
\text { receptor (BDNF) }\end{array}$ & Mecp $2^{\text {tml.1Bird }}$ & NT & Improved motor activity & $\begin{array}{l}\text { Deogracias et al. } \\
\text { (2012) }\end{array}$ & $\mathrm{Y}$ \\
\hline СРТ157633 & $\begin{array}{l}\text { PTP1B inhibitor } \\
\text { (BDNF) }\end{array}$ & Mecp $2^{\text {tml.1Bird }}$ & $\mathrm{Y}$ & $\begin{array}{l}\text { Reduced limb clasping, partially } \\
\text { improved motor activity }\end{array}$ & Krishnan et al. (2015) & - \\
\hline
\end{tabular}


Table 3 (continued)

\begin{tabular}{|c|c|c|c|c|c|c|}
\hline Treatment & Mechanism & Mouse model & $\begin{array}{l}\text { Prolong } \\
\text { lifespan }\end{array}$ & Improved phenotype & References & Clinical trial \\
\hline LM22A-4 & TrkB agonist (BDNF) & Mecp $2^{\text {tml.1Jae }}$ & NT & Improved breathing irregularity & Schmid et al. (2012) & - \\
\hline 7,8-DHF & TrKB agonist (BDNF) & Mecp $2^{\text {tml.1Jae }}$ & $\mathrm{Y}$ & $\begin{array}{l}\text { Improved motor activity and } \\
\text { breathing irregularities }\end{array}$ & Johnson et al. (2012) & - \\
\hline LM22A-4 & TrkB agonist (BDNF) & Mecp $2^{\text {tm1.1Jae }}$ & NT & Reduced apneas & Kron et al. (2014) & - \\
\hline LM22A-4 & TrkB agonist (BDNF) & Mecp $2^{\text {tm1.1Jae }}$ & NT & Improved memory & Li et al. (2017) & - \\
\hline IGF-1 & IGF-1 & Mecp $2^{\text {tm1.1Jae }}$ & $\mathrm{Y}$ & $\begin{array}{l}\text { Improves motor activity, breathing } \\
\text { irregularities, increased brain } \\
\text { size }\end{array}$ & Tropea et al. (2009) & $\mathrm{Y}$ \\
\hline PEG-IGF-1 & Slow release IGF-1 & Mecp $2^{\text {tm1.1Bird }}$ & $\mathrm{Y}$ & No improvement & Pitcher et al. (2013) & - \\
\hline RhIGF01 & $\begin{array}{l}\text { Recombinant human } \\
\text { IGF1-1 }\end{array}$ & Mecp $2^{\text {tm1.1Bird }}$ & $\mathrm{Y}$ & $\begin{array}{l}\text { Improves motor activity, breathing } \\
\text { irregularities, social behavior } \\
\text { and anxiety }\end{array}$ & Castro et al. (2014) & $\mathrm{Y}$ \\
\hline \multicolumn{7}{|l|}{ Metabolism } \\
\hline Diet restriction & Caloric deficit & $M e c p 2^{\text {tmlHzo }}$ & NT & $\begin{array}{l}\text { Improved motor activity and } \\
\text { anxiety }\end{array}$ & Mantis et al. (2009) & - \\
\hline Statins & $\begin{array}{l}\text { Cholesterol-lowering } \\
\text { medication }\end{array}$ & $\begin{array}{l}\text { Mecp2 } 2^{\text {tm1.lBird }} \\
\text { Mecp } 2^{\text {tml.1Jae }}\end{array}$ & $\mathrm{Y}$ & $\begin{array}{l}\text { Improved overall health, motor } \\
\text { coordination, motor activity, } \\
\text { serum lipids and liver lipids }\end{array}$ & $\begin{array}{l}\text { Buchovecky et al. } \\
\text { (2013) }\end{array}$ & $\mathrm{Y}$ \\
\hline Dietary triheptanoin & $\begin{array}{l}\text { Energy use (mitochon- } \\
\text { dria) }\end{array}$ & Mecp $2^{\text {tml.1Jae }}$ & $\mathrm{Y}$ & $\begin{array}{l}\text { Improved motor coordination, } \\
\text { social behavior, insulin sensitiv- } \\
\text { ity, metabolic homeostasis }\end{array}$ & Park et al. (2014) & $\mathrm{Y}$ \\
\hline Trolox & Vitamin E derivative & Mecp $2^{\text {tml. } 1 \text { Bird }}$ & NT & $\begin{array}{l}\text { Blood glucose levels normalized, } \\
\text { improved response to hypoxia }\end{array}$ & Janc et al. (2016) & - \\
\hline Corticosterone & $\begin{array}{l}\text { Glucocorticoid activa- } \\
\text { tion }\end{array}$ & Mecp $2^{\text {tml. } 1 \text { Bird }}$ & $\begin{array}{c}\text { Decreased } \\
\text { lifespan }\end{array}$ & Worsened motor activity & Braun et al. (2012) & - \\
\hline Corticosterone & $\begin{array}{l}\text { Glucocorticoid activa- } \\
\text { tion }\end{array}$ & $M e c p 2^{\operatorname{tmlHzo}}$ & NT & Improved motor activity & $\begin{array}{l}\text { De Filippis et al. } \\
\text { (2013) }\end{array}$ & - \\
\hline RU486 & $\begin{array}{l}\text { Glucocorticoid repres- } \\
\text { sion }\end{array}$ & Mecp $2^{\text {tml. } 1 \text { Bird }}$ & No & $\begin{array}{l}\text { Delayed progression of symptoms, } \\
\text { improved motor activity }\end{array}$ & Braun et al. (2012) & - \\
\hline Curcumin & $\begin{array}{l}\text { Anti-oxidant, anti- } \\
\text { inflammatory }\end{array}$ & Mecp $2^{\text {tml.1Jae }}$ & NT & NT & Panighini et al. (2013) & - \\
\hline Insulin & Glucose signaling & $\operatorname{Mecp} 2^{\text {tml.1.1Bird }}$ & $\begin{array}{c}\text { Decreased } \\
\text { lifespan }\end{array}$ & No improvement & Pitcher et al. (2013) & - \\
\hline \multicolumn{7}{|l|}{ Other } \\
\hline Zoledronic acid & Anti-osteoclastic & Mecp $2^{\text {tml. } 1 \text { Bird }}$ & NT & $\begin{array}{l}\text { Increased bone volume and con- } \\
\text { nectivity }\end{array}$ & Shapiro et al. (2010) & - \\
\hline Cannabidivarin & Phytocannabinoid & $M e c p 2^{\operatorname{tmlHzo}}$ & NT & $\begin{array}{l}\text { Improved overall health, motor } \\
\text { activity and social behavior }\end{array}$ & Vigli et al. (2018) & - \\
\hline CNF1 & RhoGTPase & $M e c p 2^{\operatorname{tmlHzo}}$ & NT & Improved motor activity & $\begin{array}{l}\text { De Filippis et al. } \\
\text { (2012) }\end{array}$ & - \\
\hline CNF1 & Rho GTPase & $M e c p 2^{\operatorname{tmlHzo}}$ & NT & $\begin{array}{l}\text { Improved mitochondrial dysfunc- } \\
\text { tion and memory }\end{array}$ & $\begin{array}{l}\text { De Filippis et al. } \\
\text { (2015) }\end{array}$ & - \\
\hline \multicolumn{7}{|l|}{ Non-pharmacological } \\
\hline Enriched environment & $\begin{array}{l}\text { Environmental modula- } \\
\text { tion }\end{array}$ & Mecp $2^{\text {tmlPplt }}$ & NT & Improved motor coordination & Kondo et al. (2008) & - \\
\hline Enriched environment & $\begin{array}{l}\text { Environmental modula- } \\
\text { tion }\end{array}$ & Mecp $2^{\text {tm1.1Jae }}$ & NT & Improved motor activity & Nag et al. (2009) & - \\
\hline Enriched environment & $\begin{array}{l}\text { Environmental modula- } \\
\text { tion }\end{array}$ & Mecp $2^{\text {tm1.1Jae }}$ & $\mathrm{N}$ & $\begin{array}{l}\text { Improved motor coordination and } \\
\text { activity }\end{array}$ & Lonetti et al. (2010) & - \\
\hline Enriched environment & $\begin{array}{l}\text { Environmental modula- } \\
\text { tion }\end{array}$ & Mecp $2^{\text {tmlPplt }}$ & NT & Reduced anxiety & Kondo et al. (2016) & - \\
\hline
\end{tabular}


Table 3 (continued)

\begin{tabular}{|c|c|c|c|c|c|c|}
\hline Treatment & Mechanism & Mouse model & $\begin{array}{l}\text { Prolong } \\
\text { lifespan }\end{array}$ & Improved phenotype & References & Clinical trial \\
\hline $\begin{array}{l}\text { Forniceal deep brain } \\
\text { stimulation }\end{array}$ & $\begin{array}{l}\text { Neural circuit stimula- } \\
\text { tion }\end{array}$ & Mecp $2^{\text {tml.1Bird }}$ & NT & Improved memory & Hao et al. (2015) & - \\
\hline $\begin{array}{l}\text { Bone marrow transplan- } \\
\text { tation }\end{array}$ & $\begin{array}{l}\text { Brain microglia repopu- } \\
\text { lation }\end{array}$ & Mecp $2^{\text {tml.1Bird }}$ & $\mathrm{Y}$ & $\begin{array}{l}\text { Reduced apneas, improved breath- } \\
\text { ing irregularities, improved } \\
\text { locomotor activity }\end{array}$ & Derecki et al. (2012) & - \\
\hline
\end{tabular}

Treatment strategies are divided into those influencing neurotransmitter signaling, growth factor signaling, metabolism, other pharmacological treatments, and non-pharmacological treatments. In prolong lifespan column, $Y$ yes, $N$ no, $N T$ not tested. In clinical trial column, $Y$ yes, $-:$ not yet tested

challenge is specificity: $M E C P 2$ is recruited to DNA methylation signals, which are highly cell-specific (Cedar 1988; Deaton et al. 2011). Therefore, the genes MECP2 regulates will likely vary based on methylation status in different cell types. Consistently, a recent study found that gene misregulation within subtypes of neurons in Mecp 2 mutant mice is highly dependent on cell type-specific epigenetic marks (Renthal et al. 2018). Finally, it is difficult to discern which pathways are affected as the primary result of MECP2 loss and which are secondary effects farther downstream that will likely have less value as therapeutic targets. Nevertheless, advances in molecular biology techniques are making it easier to circumvent these issues. For example, single-cell RNA sequencing can identify genes misregulated in individual Mecp2-deficient cells and chromatin immunoprecipitation of $M E C P 2$ 's known binding partners could identify its direct transcriptional targets in individual cells. Here, we highlight preclinical treatments targeting pathways downstream of Mecp2 which have led to clinical trials in RTT patients.

\section{Potential treatments targeting neurotransmitter signaling}

A prominent feature of RTT and Mecp2-mutant mouse models is the reduction in the number and length of dendrites (Armstrong 1992). Since dendrites receive electrical signals and neurotransmitters from pre-synaptic neurons, a neurotransmitter signaling defect was proposed in RTT. In support of this idea, dysfunction in dopamine (Wenk 1995), serotonin (Paterson et al. 2005; Ohno et al. 2016), norepinephrine (Viemari 2005; Santos et al. 2010), glutamate (Chao et al. 2010; Abdala et al. 2016), and NMDA signaling (Katz et al. 2016; Patrizi et al. 2016) has been observed in Mecp2mutant mice. Treatments that target these pathways have shown varied effects in mice, and a few have been tested in clinical trials. Desipramine, a norepinephrine reuptake inhibitor, improved breathing irregularities and apneas in Mecp2-mutant mice (Roux et al. 2007; Zanella et al. 2008). However, a clinical trial found no clinical improvements in RTT patients treated with this drug (Mancini et al. 2018). In contrast, sarizotan, a serotonin 1a agonist and dopamine D2-like receptor, reduced breathing apneas by $15-30 \%$ in Mecp2-mutant mice but had no effect on motor activity (Abdala et al. 2014). As a result, it is currently being tested for its efficacy in improving respiratory symptoms in RTT (NCT02790034).

Finally, ketamine, an NMDA receptor agonist, was tested in two different laboratories for its therapeutic potential in RTT (Kron et al. 2012; Patrizi et al. 2016). These preclinical studies showed that low-dose ketamine could increase activity in the cortical network while decreasing synaptic excitability in the brainstem network, targeting a possible imbalance in neuronal activity throughout the Mecp2-mutant brain. Treatment with ketamine improved limb clasping, motor coordination, and breathing apneas in Mecp2-mutant mice. The safety of ketamine is currently being assessed in RTT patients (NCT03633058).

\section{Growth factor signaling as a treatment for RTT}

Early studies of $M E C P 2$ identified BDNF as one of its transcriptional targets (Chen et al. 2003). BDNF is a member of the neurotrophin family of growth factors, which binds to tropomyosin-related kinase B (TrkB) to stimulate signaling cascades involved in neurite outgrowth, synaptic function, and neuronal differentiation (Amaral and Pozzo-Miller 2007). In RTT patients and Mecp2-mutant mice, brain Bdnf expression is drastically reduced (Chang et al. 2006; Deng et al. 2007). However, direct administration of BDNF is not a feasible treatment option because it is unable to cross the blood-brain barrier (BBB). However, fingolimod (FTY720), 
a sphingosine-1 phosphate analog, has been shown to partially increase BDNF levels and improve motor activity in Mecp2-mutant mice (Deogracias et al. 2012). Fingolimod is currently being assessed for its safety and efficacy in patients (NCT02061137).

Insulin-like growth factor-1 (IGF) binds to the IGF-1 receptor (IGF-1R), activating a signaling cascade similar to the BDNF receptor TrkB. IGF-1 is also transcriptionally regulated by $M E C P 2$ (Itoh et al. 2007), but unlike BDNF, it can cross the $\mathrm{BBB}$, increasing its therapeutic potential (Baker et al. 2005). IGF-1 signaling is involved in neuronal survival, neural outgrowth, and synapse formation (D'Ercole et al. 1996). It has been implicated as a promising therapeutic in cancer, diabetes, and ALS.

Mecp2-mutant mice treated with IGF-1 showed improved locomotor function, breathing irregularities, and extended lifespan. IGF-1 also increased the brain weight of mutant mice while restoring neural spine density in the motor cortex and improving excitatory synaptic transmission in sensorimotor cortex neurons (Tropea et al. 2009). Importantly, full-length IGF-1 is already an approved treatment in North America used to treat growth failure in children. A phase 1 clinical trial in RTT patients found no adverse effects of recombinant human IGF-1 (rhIGF-1) (Khwaja et al. 2014). However, subsequent clinical trials found it produced no significant improvement of RTT symptoms (O'Leary et al. 2018).

Recently, a synthetic analog derived from IGF-1, NNZ2566 (Trofinetide) was developed which inhibits neuroinflammation, restores glial function, corrects synaptic deficits, and regulates oxidative stress response (Deacon et al. 2015). When administered to mice with Fragile $X$ syndrome, NNZ-2566 drastically improved their aberrant symptoms (Ligsay and Hagerman 2016). A phase 2 clinical trial of NNZ-2566 in RTT patients showed that treatment improved overall health, neurobehavioral and motor symptoms. These promising results enabled a phase 3 clinical trial that is currently recruiting patients (NCT02715115).

\section{Metabolic defects in RTT can be therapeutically targeted}

Modifiers of $M E C P 2$ have implicated neurite outgrowth and energy homeostasis in altering phenotypic outcome in human patients (Artuso et al. 2011; Pizzo et al. 2018). Modifiers are also being identified and validated by carrying out modifier screens in a mouse model (Buchovecky et al. 2013). In a modifier screen, unbiased random mutation identifies key genes that can change a phenotype of interest, allowing the model to reveal important pathways of interest. Such an approach was applied to identify novel therapeutic targets in RTT; ethylnitrosourea (ENU), a mouse supermutagen, was used to induce mutations in male mice, which were then bred to females carrying a mutant Mecp2. Male mice inheriting mutant Mecp2 would normally become very ill and die. Dominant second site mutations that could improve the health and neurological phenotype of the Mecp2 mutant males were then identified molecularly (Buchovecky et al. 2013). One suppressor of disease was a nonsense mutation in a rate-limiting enzyme in cholesterol synthesis-a pathway that had not previously been associated with RTT.

The identification of this modifier locus led to additional studies that revealed lipid metabolism was severely perturbed in Mecp2-mutant mice. Prior to symptom onset, brain cholesterol was already markedly elevated in Mecp2mutant mice, and cholesterol and triglycerides were elevated in the serum and liver. Remarkably, lipid-lowering statin drugs regulated lipid levels, ameliorated motor symptoms, and extended lifespan in mice (Buchovecky et al. 2013). Furthermore, elevated lipids have also been observed in a subset of RTT patients, indicating that repurposing of statin drugs may be a viable treatment option to benefit patients (Justice et al. 2013; Segatto et al. 2014). Abnormalities in cholesterol homeostasis are associated with many neurological diseases (Tint et al. 1994; Puglielli et al. 2003; Bi and Liao 2010; Berry-Kravis et al. 2015), and therefore RTT is no exception. Importantly, these findings led to a clinical trial testing the efficacy and safety of statins in RTT patients (NCT02563860).

Metabolic defects in RTT are not limited to cholesterol synthesis. Both RTT patients and Mecp2-mutant mouse models display abnormal mitochondrial structure and function (Eeg-Olofsson et al. 1988; Dotti et al. 1993; Kriaucionis et al. 2006; Gold et al. 2014). Mitochondria are organelles within cells that convert glucose into adenosine triphosphate (ATP), the energy currency of the cell. Importantly, compromised mitochondrial function can greatly affect cellular energy production. While mitochondria are necessary in all cells of the body, their role is especially important in tissues with high energy demands, such as nerves and muscle. RTT shares many features of mitochondrial diseases, including early symptomatic onset, developmental delay, neurological regression, poor muscle tone, seizures, and gastrointestinal issues (Schon and Manfredi 2003). Consistently, both RTT patients and Mecp2-mutant mice present with increased oxidative stress and decreased levels of mitochondrial enzymes (Haas et al. 1995; Kriaucionis et al. 2006; De Felice et al. 2009; Leoncini et al. 2011). In Mecp2-mutant mice, markers of oxidative stress increase with age, suggesting a progressive dysfunction in mitochondrial function (De Felice et al. 2014). Altogether, this suggests defects in mitochondrial energy production may be present in RTT. Importantly, mitochondrial energy production is tightly linked with cholesterol synthesis. Several steps in the biosynthesis of cholesterol require mitochondrial sources of ATP as an electron donor in oxygenation reactions. Thus, cholesterol 
perturbations may be linked with mitochondrial dysfunction in RTT.

Interestingly, anaplerotic substances can replenish intermediate compounds in the energy production pathway, enhancing mitochondrial energy production. A diet supplemented with the anaplerotic triheptanoin reversed symptoms of some metabolic disorders by correcting energy production (Roe et al. 2002; Mochel et al. 2005). This strategy was adapted for use in mouse models of RTT. Strikingly, Mecp2mutant mice fed a diet with triheptanoin supplementation showed improved mitochondrial morphology and improved energy production. This translated to improved motor coordination and increased lifespan in these mice. Two clinical trials investigating the efficacy of triheptanoin in improving seizures, muscle tone, and symptom improvement in RTT patients are currently in their early stages (NCT02696044 and NCT03059160).

\section{Using mouse models to develop therapies for RTT that directly target MECP2}

Directly restoring $M E C P 2$ is an attractive therapeutic strategy (Fig. 3) since all pathways downstream of $M E C P 2$ could subsequently recover as well. However, the largest concern of these approaches is dosage. While lack of $M E C P 2$ causes RTT, an abundance of $M E C P 2$ causes $M E C P 2$ duplication syndrome, a disorder characterized by neurological dysfunction, intellectual disability, and some RTT-like features (Van Esch et al. 2005). In mice, MECP 2 overexpression causes hypoactivity and seizures (Collins et al. 2004; Bodda et al. 2013). The amount of $M E C P 2$ required to cause toxicity associated with overexpression has been debated, with some studies finding that $1.6 \times$ normal levels of $M E C P 2$ cause behavioral impairments in mice (Jugloff, 2008) and others finding that $2.4 \times$ normal $M E C P 2$ can be tolerated (Koerner et al. 2018). Despite this discrepancy, small deviations in $M E C P 2$ levels in humans have been linked to milder neurological and psychiatric conditions including autism, intellectual disability, and lupus erythematosus. Thus, caution must be taken to provide enough $M E C P 2$ per cell to impart a therapeutic benefit while reducing the risk of $M E C P 2$ overexpression.

\section{Read-through compounds may facilitate the recovery of $M E C P 2$ product}

One strategy involves directly targeting the $M E C P 2$ mutation with small molecules known as translational readthrough-inducing drugs (TRIDs). This is an attractive strategy for $35-40 \%$ of Rett syndrome patients who have nonsense mutations in $M E C P 2$ that result in premature stop codons, which inhibit normal full-length protein expression
(Neul et al. 2008). TRIDs permit read-through of premature stop codons by binding to ribosomes and impairing codon/ anticodon recognition, allowing for the insertion of another amino acid in place of the stop codon (Nagel-Wolfrum et al. 2016). Notably, this causes a missense mutation rather than a nonsense mutation, which may impart less of a functional consequence on the protein product. Importantly, this strategy would increase $M E C P 2$ in cells with the nonsense mutation, while avoiding increasing dosage in cells with normal $M E C P 2$. However, because TRIDs would create a mutated $M E C P 2$ rather than a fully functional protein, this treatment strategy may only modestly improve symptoms in patients. An additional concern is nonsense mediated decay (NMD), a cellular process that facilitates the degradation of mRNA transcripts with premature stop codons because their translation could lead to mutated proteins with deleterious gainof-function or dominant-negative effects (Conti and Izaurralde 2005). In mammalian cells, when a premature stop codon is located greater than 50-55 nucleotides away from an exon-exon junction, NMD is activated (Nagy and Maquat 1998; Kuzmiak and Maquat 2006). NMD naturally reduces the number of transcripts available for TRIDs (Linde et al. 2007). Therefore, TRIDs may not be a suitable treatment option for RTT patients with certain nonsense mutations which are prone to NMD as the best responders will have high levels of target transcript. However, the efficacy of NMD varies naturally between individuals (Nguyen et al. 2014) and patient transcript levels could be assayed to determine if they are candidates for TRID therapy.

One class of TRIDs is aminoglycoside antibiotics, of which gentamicin is the most commonly studied. Gentamicin has been shown to suppress nonsense mutations and restore function protein in mouse models of Duchenne muscular dystrophy (DMD) (Barton-Davis et al. 1999), cystic fibrosis (CF) (Du et al. 2008), retinal degeneration (Guerin et al. 2008), and several other diseases. Importantly, clinical trials in DMD and CF patients have demonstrated gentamicin's ability to restore protein products in a subset of patients, giving hope for the effectiveness of TRIDs in other diseases (Nagel-Wolfrum et al. 2016).

Four of the most common RTT-causing mutations (R168X, R255X, R270X, R294X) result in premature stop mutations. In vitro studies have shown that read-through efficiency of gentamicin depends heavily on the context of the stop mutation, where gentamicin restored $22 \%$ of function MECP2 in cells with R294X mutations and only $10 \%$ in cells with R168X (Brendel et al. 2011), possibly due to variable NMD. Increasing the concentration of gentamicin increased read-through efficiency and amounts of $M E C P 2$ protein. However, these high levels of aminoglycosides could cause toxic side effects if administered over a long period of time (Popescu et al. 2010). Novel aminoglycosides and different TRIDs may impart higher read-through activity 
and lower toxicity (Brendel et al. 2011; Pitcher et al. 2015), though no in vivo tests with these novel compounds have performed in Mecp2-mutant mice.

One new promising TRID is Ataluren, an orally bioavailable oxadiazole with no antibacterial activity and minimal off-target effects (Keeling et al. 2014). Ataluren restored $20 \%$ of normal functional protein in mouse models of DMD and $\mathrm{CF}$, leading to clinical trials for both diseases. However, in both cases, Ataluren did not produce enough protein to see a significant benefit in patients (Kerem et al. 2014; McDonald et al. 2017). This may be a worthwhile avenue to pursue for RTT since even small increases in $M E C P 2$ are associated with improved symptoms. Nonetheless, efforts are underway to improve the efficacy of TRIDs for suppression therapy, making them more likely to assist RTT patients.

\section{Reactivating the silent $\mathrm{X}$ chromosome could restore endogenous MECP2 to cells}

Through XCI, mammalian cells silence one X chromosome in each cell, allowing for dosage compensation of X-linked genes (Bhatnagar et al. 2014). XCI is initiated by the noncoding RNA Xist, which coats the inactive X chromosome (Xi) from which it is produced. On the active $\mathrm{X}(\mathrm{Xa}), T$ six RNA blocks Xist upregulation. As MECP2 is expressed on the $\mathrm{X}$ chromosome, one copy is silenced by XCI. Therefore, in cells of RTT patients where the mutated $M E C P 2$ is on the $\mathrm{Xa}$, a normal copy of $M E C P 2$ lies dormant on the $\mathrm{Xi}$.

Interestingly, the silent state of the $\mathrm{Xi}$ is temporarily reversed during development and stem cell remodeling. In the case of X-linked diseases, identification of key molecular players involved in reactivation of the Xi could be repurposed to facilitate the re-expression of its genes. Using this strategy to target $M E C P 2$ could provide a viable treatment option for RTT patients (Vacca et al. 2016). This is an attractive strategy for RTT because patient cells could use their own regulatory functions to control MECP 2 expression. However, sex chromosome dosage is an important developmental process and reactivating the second $\mathrm{X}$ chromosome may lead to a pathological level of expression for other $\mathrm{X}$ chromosome loci. Ideally, these strategies will aim to target the $M E C P 2$ gene or its local vicinity alone. Additionally, the Xi can be difficult to reactivate due to multiple mechanisms of epigenetic silencing and attempting to disengage these processes could disrupt epigenetic patterns throughout the genome which could cause adverse long-term effects. Finally, because RTT patients are heterozygous mosaics for $M E C P 2$ mutation, approximately half of their cells already express a normal copy of $M E C P 2$. Thus, Xi reactivation will lead to $2 \mathrm{x}$ the normal amount of $M E C P 2$ in these cells. In patients carrying mutations that only reduce efficiency of $M E C P 2$ rather than destroy its function, $\mathrm{Xi}$ reactivation will lead to anywhere from 1 to $2 \mathrm{x}$ the normal amount of $M E C P 2$ in some cells. This could lead to symptoms associated with overexpression of $M E C P 2$. Therefore, $\mathrm{Xi}$ reactivation will need to be adapted to target only $M E C P 2$ or its local vicinity, and may only be a practical treatment option for patients who have loss-of-function mutations in $M E C P 2$.

One group reactivated the $\mathrm{Xi}$ using an antisense oligonucleotide to 5-aza-2'-deoxycytidine (Aza), a DNA methylation inhibitor, in a mouse with an Xist deletion on one chromosome and Mecp2-GFP on the other. This ensured that Mecp2-GFP was silenced in almost all cells. Treatment resulted in a great increase in GFP expression, indicating that Mecp 2 could be targeted by Xi reactivation tools (Carrette et al. 2017). Recently, a heterozygous female mouse was engineered with a mutation of Tsix on one chromosome and a null mutation of Mecp 2 on the other, directing the preferential expression of the chromosome with the mutated Mecp2 (Carrette et al. 2018). This strategy achieved a Mecp2-null female mouse with all cells expressing the same Xa. Additionally, this group found that while Mecp2-null females had a shortened lifespan, a 5\% increase in MECP2 levels increased the lifespan by $50 \%$, and a $10-20 \%$ increase in $M E C P 2$ restored a normal lifespan (Carrette et al. 2018). Thus, small increases in $M E C P 2$ can have great positive impacts on life expectancy. However, as a global inhibitor of methylation, Aza is toxic when administered over a long time course. Ongoing screens aim to identify new molecules to induce Xi reactivation that can be further tested and optimized for treatment (Bhatnagar et al. 2014; Minkovsky et al. 2015; Sripathy et al. 2017). Importantly, the unique mice designed in these studies will provide an excellent avenue to test candidate Xi-reactivating drugs specifically for the treatment of RTT.

\section{Gene therapy}

A final potential avenue of treatment for RTT involves introducing a normal copy of $M E C P 2$ into cells by gene therapy. Gene therapy is a promising approach for the treatment of many disorders and has been successful in reversing symptoms in mouse models of CF, hemophilia, Hunter syndrome, diabetes, obesity, ALS, and more. Recently, the first targeted gene therapy treatment was approved in North America to treat patients with Lever's congenital amaurosis, a rare inherited eye disease (Kumaran et al. 2018).

To treat RTT, gene therapy approaches must utilize an appropriate vector able to cross the $\mathrm{BBB}$ and transduce many cells in the CNS, and able to maintain stable long-term expression of the exogenously derived MECP2. Additionally, strategies must be developed to avoid transgene repression and avoid overexpression of $M E C P 2$. Like Xi reactivation, gene therapy targets all cells regardless of $M E C P 2$ mutation status. Thus, cells expressing normal $M E C P 2$ will have $2 \mathrm{x}$ the normal level of the protein leading to potential 
toxic effects of $M E C P 2$ overexpression. An additional concern of gene therapy is that high viral titres are often needed to infect a large proportion of cells, but cells that inadvertently receive more than one viral particle, and hence more than one copy of $M E C P 2$, would be overburdened. Strategies to circumvent these issues could supply a factor such as an siRNA to suppress endogenous $M E C P 2$ so that only the transgenic MECP2 is expressed (Gadalla et al. 2011). However, this would require the transgenic MECP2 to possess a seamless promoter to completely mimic endogenous gene expression. MicroRNAS (miRNAs) have been used to control exogenous transgene expression by mediating the degradation of transgene mRNAs in a tissue-specific manner and may be beneficial in RTT gene therapy approaches to limit off-target toxicity (Geisler and Fechner 2016).

Recombinant adeno-associated virus (AAV) vectors have been used in preclinical gene therapy studies for their ability to cross the BBB, infect neurons, and mediate stable long-term expression of the transgene without inflammation or toxicity (Gonçalves 2005; Foust et al. 2009). AAV has a $4.7-\mathrm{kb}$ ssDNA genome from which $4.4 \mathrm{~kb}$ of the viral DNA can be removed and replaced with a human transgene. Self-complementary (sc) AAV vectors have a 10-100-fold higher transduction efficiency, but their drawback is that their packaging capacity is cut in half to only $2.2 \mathrm{~kb}$, making it difficult to package large genes (McCarty et al. 2001). When AAV9-MECP 2 under the promoter of chicken $\beta$-actin was injected into the brains of neonatal Mecp2-null mice, transduction efficiency varied between brain regions from 7 to $42 \%$ of cells infected, with the highest infection rate in the hypothalamus and lowest in the striatum (Gadalla et al. 2013). However, this low efficiency of infection was sufficient to increase lifespan of male mice to 16.6 weeks and improve motor impairments, but it did not have any effect on respiratory symptoms. In contrast, scAAV9-MECP 2 under a truncated Mecp 2 promoter injected into mice systemically had a very low transduction efficiency in the brain of 2-4\%. Despite this, mice survived to 15 weeks, indicating that low levels of $M E C P 2$ re-expression in the brain and/or re-expression in non-CNS tissues could modestly improve lifespan. Notably, AAV9 preferentially targeted the liver and spleen, with some cells in these tissues receiving ten copies of the vector and causing liver damage. Therefore, future studies must increase the specificity of AAV9 therapy before moving to the clinic.

A subsequent study delivered scAAV9-MECP2 under a truncated Mecp 2 promoter systemically and found a range of transduction efficiencies in the brain from $10 \%$ in the cerebellum to $25 \%$ in the cortex and brainstem (Garg et al. 2013). This produced some behavioral improvements but did not rescue breathing symptoms. A second-generation AAV9 vector with a modified 3'UTR and a panel of miRNA binding sites was developed with the goal of biasing transgene expression away from the liver (Sinnett et al. 2017). This vector, injected in the cisterna magna, was better tolerated and improved the lifespan of Mecp 2 mutant mice but could not improve behavioral traits without being used at very high doses. However, direct cerebroventricular injection of this vector into neonatal Mecp2-null mice resulted in a high brain transduction efficiency, increased survival, and the amelioration of RTT-like phenotypes, highlighting the importance of endogenous regulatory elements in the gene expression cassette (Gadalla et al. 2017).

Finally, a recent study designed a minimal-MECP 2 protein lacking all amino acids except those encoding two functional domains: the methyl-binding domain, and the NCORinteraction domain (Tillotson et al. 2017). When neonatal mice were injected intracranially with a scAAV9 vector encoding this minimal protein, they showed improved phenotypes and survival in the absence of toxic effects, indicating that the primary role of $M E C P 2$ is to physically connect the NCOR-containing complex to DNA. This study provides a new avenue to pursue in gene therapy studies as a functional minimal MECP 2 protein creates room for additional regulatory sequences to be packaged into the limited capacity of scAAV9 vectors. Importantly, this would allow for more precise temporal control of Mecp 2 expression. Future studies should aim to introduce additional regulatory elements into the gene therapy vector while also controlling for timing of treatment to best represent therapeutic utility in human patients.

An additional obstacle of gene therapy treatment for any disorder involves scaling the dosage for humans. Due to their small size, mice cannot reliably inform effective dosages for clinical applications. Therefore, gene therapy treatment is being tested in other animal models including canines and non-human primates. The brains of non-human primates are similar to humans with regard to neural circuitry, physiology, and behavioral characteristics, making them an ideal model to test gene therapy for neurological diseases (Gopinath et al. 2015). However, studies in larger models are expensive and require longer experimental periods. Importantly, primate models lacking $M E C P 2$ have been generated which can be utilized to accelerate gene therapy treatment for RTT (Liu et al. 2014; Chen et al. 2017). Recently, systemic administration of high-dose AAV9 was found to cause severe liver and neuronal toxicity in three non-human primates indicating that efforts in dosage optimization will be imperative (Hinderer et al. 2018). 


\section{The need for precision medicine for a monogenic disease}

Rare diseases have limited statistical power in clinical trials making animal models our greatest opportunity at developing, adapting, and enhancing therapeutics to be clinical trial-ready. Importantly, treatments that are rigorously tested and streamlined for efficiency before advancing to human trials achieve higher levels of success than those for which multiple preclinical trials are not conducted (Morgan et al. 2018). To do this, studies should address age- and methoddependent effects of treatments. For example, in the case of gene therapy, treatment is often more effective in neonatal mice compared to adult mice, or through direct brain injection compared to systemic administration. It is likely that most treatment options will be more effective if delivered to patients early, but as this is not always feasible, preliminary studies should aim to recapitulate treatment methods available in human patients. This would involve testing treatments in Mecp 2 mutant mice after symptom onset. Additionally, identifying and publishing negative effects of potential therapeutics is beneficial as they inform about off-target effects and toxicity. This ultimately provides better criteria to assess the safety of treatments that will lead to the development of more effective therapeutic strategies.

While many potential treatments for RTT have been identified in model organisms, many have not shown extreme efficacy in human trials. Clinical trial design for rare diseases is especially important due to the sparsity of patients. In diseases like RTT where there is substantial variability in clinical presentation, patient stratification should be considered to reduce the variability in the sample and maximize the potential to detect efficacy (Modi and Sahin 2018). Natural history studies assessing genotype-phenotype correlations, symptom progression, and biomarkers of disease may provide tools to identify patients likely to respond to new treatments. For example, there may be critical windows in which specific interventions will have a maximal effect. Additionally, clinical trials should be designed with enough statistical power for the endpoints being tested, with consideration given to placebo effects.

Given the drastic variation in phenotype presentation, it is likely that every RTT patient is unique and will not respond to the same treatment. In this respect, precision medicine for RTT is warranted (Fig. 4). Precision medicine approaches are taken because patients carrying different mutations do not always respond to treatments in the same way. Ideally, RTT patient age, their specific mutation and individual level of XCI skewing should be taken into consideration when developing a personalized treatment regimen. It is likely that some patients will make excellent candidates for gene therapy, mutation read-through, or reactivation of the silent $\mathrm{X}$ chromosome, while others may not benefit greatly from any of these treatments.

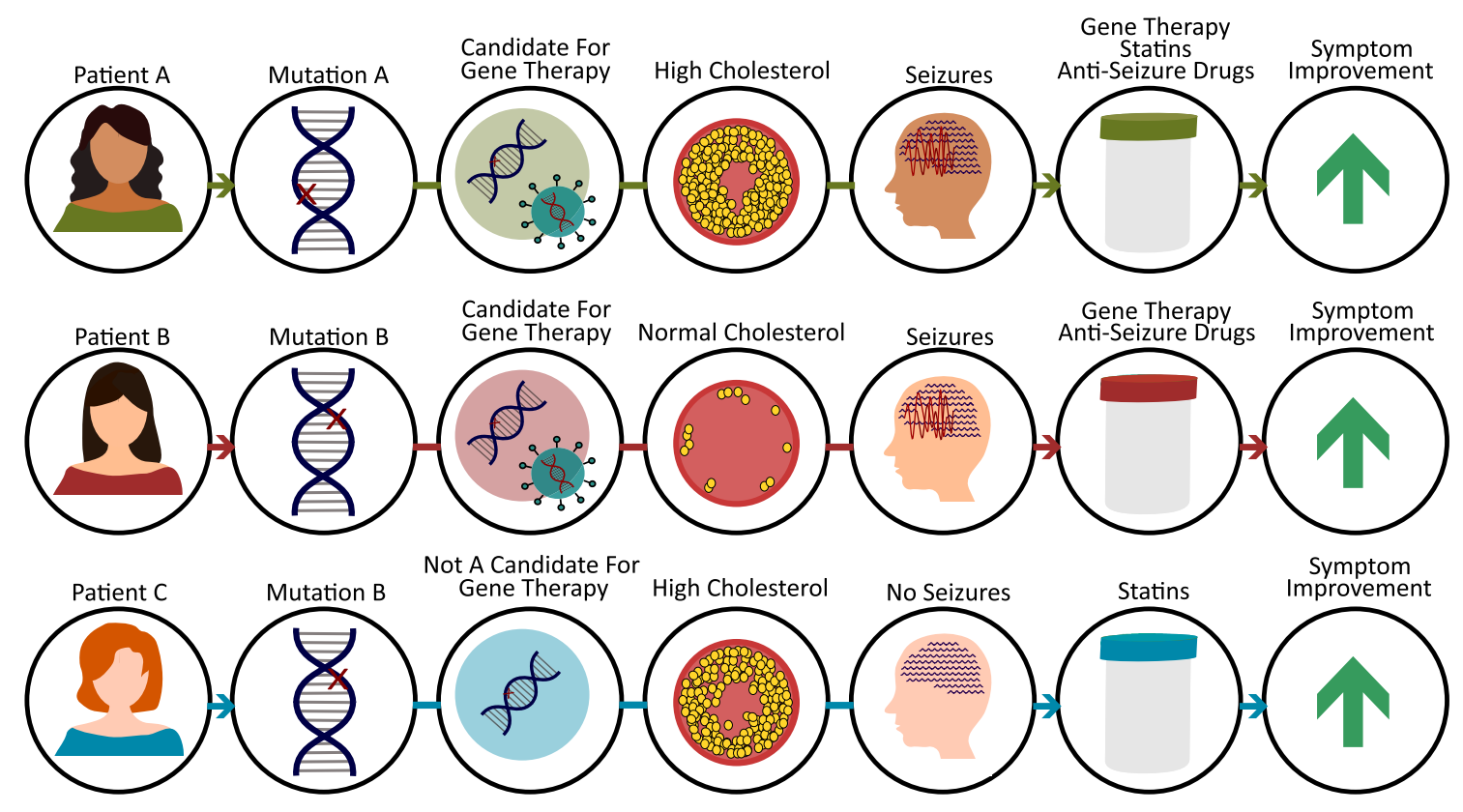

Fig. 4 Precision medicine for RTT. Different RTT patients will likely benefit from different combinations of treatment. When treating patients for RTT, their mutation status and XCI skewing should be taken into consideration. It is likely some patients will not be ideal candidates for gene therapy. Biomarkers, such as serum cholesterol, can be used to determine which patients will benefit from pharmacological intervention, such as statins. Management of other symptoms (seizures, scoliosis, lung infection, etc.) should also be considered. Together, RTT patients should receive individualized treatment to maximize their symptom improvement 
As CNS-targeted gene therapy becomes a more realistic therapeutic approach, peripheral deficiency of $M E C P 2$ also needs to be considered. Loss of MECP2 in non-CNS tissues is associated with cardiac defects (Hara et al. 2015), decreased bone density (Haas et al. 1997), urological dysfunction (Ward et al. 2016), elevated lipid metabolism (Justice et al. 2013; Segatto et al. 2014), and increased oxidative stress (Leoncini et al. 2011). It is likely that when $M E C P 2$ is genetically treated exclusively in the brain, these peripheral symptoms will persist. For this reason, biomarkers of nonCNS perturbations in RTT are needed to ensure adequate treatment. For example, high serum cholesterol or increased oxidative stress can be used as an indicator for statin or triheptanoin treatment, respectively. As more perturbed pathways downstream of Mecp 2 mutation are discovered, it is likely that the list of biomarkers for pharmacological intervention will increase. Importantly, patients should continue to be assessed for seizures, scoliosis, lung infection, and other features of RTT that present differently in each patient. Ultimately, because small increases in MECP2 can lead to drastic improvements (Carrette et al. 2018), it is probable that a combination of gene therapy paired with personalized pharmacological treatments will provide the best efficacy to treat most RTT patients. Treating each patient individually is expensive which can reduce profit for drug companies. However, the NIH instituted an orphan drug program to provide incentives for pharma companies to develop treatments for rare diseases such as RTT (Engstrom 1985).

Although it is a rare disorder, RTT has served as a paradigm for the understanding and developing treatments for rare diseases because of the early development of mouse models, intensive mechanistic studies, a NIH-funded natural history study (NCT02738281), and funding by focused patient groups (International Rett Syndrome Foundation and Rett Syndrome Research Trust). Because it is a complex disorder involving many organ systems, it is likely that recovery of RTT patients will involve a combination of treatments. Model organisms will continue to serve as an indispensable tool in accelerating drug discovery and adapting therapeutics, leading to better treatment strategies for many rare disorders.

Acknowledgements We thank all the girls with Rett syndrome and their families who provide the motivation for our group to try to alleviate symptoms. We thank Julie Ruston, Adebola Enikanolaiye, and Rebekah Tillotson for their critical comments on the manuscript.

Funding MJJ and NV were supported by grants from the Canadian Institute for Health Research (CIHR) and the Angel Ava Fund while writing this review.

\section{Compliance with ethical standards}

Conflict of interest All authors declare that they have no conflict of interest.

Open Access This article is distributed under the terms of the Creative Commons Attribution 4.0 International License (http://creativeco mmons.org/licenses/by/4.0/), which permits unrestricted use, distribution, and reproduction in any medium, provided you give appropriate credit to the original author(s) and the source, provide a link to the Creative Commons license, and indicate if changes were made.

\section{References}

Abdala APL, Dutschmann M, Bissonnette JM, Paton JFR (2010) Correction of respiratory disorders in a mouse model of Rett syndrome. Proc Natl Acad Sci. https://doi.org/10.1073/pnas.10121 04107

Abdala AP, Lioy DT, Garg SK et al (2014) Effect of sarizotan, a 5-HT1aand D2-like receptor agonist, on respiration in three mouse models of rett syndrome. Am J Respir Cell Mol Biol. https://doi.org/10.1165/rcmb.2013-0372OC

Abdala AP, Toward MA, Dutschmann M et al (2016) Deficiency of GABAergic synaptic inhibition in the Kölliker-Fuse area underlies respiratory dysrhythmia in a mouse model of Rett syndrome. J Physiol 594:223-237. https://doi.org/10.1113/JP270966

Alpoz AR, Ergul N, Oncag O (1999) Bruxism in Rett syndrome: a case report. J Clin Pediatr Dent 23:161-163

Amaral MD, Pozzo-Miller L (2007) TRPC3 channels are necessary for brain-derived neurotrophic factor to activate a nonselective cationic current and to Induce dendritic spine formation. J Neurosci 27:5179-5189. https://doi.org/10.1523/JNEUR OSCI.5499-06.2007

Amir RE, Van den Veyver IB, Wan M et al (1999) Rett syndrome is caused by mutations in X-linked MECP2, encoding methylCpG-binding protein 2. Nat Genet 23:185-188. https://doi. org/10.1038/13810

Anderson A, Wong K, Jacoby P et al (2014) Twenty years of surveillance in Rett syndrome: what does this tell us? Orphanet J Rare Dis 9:87. https://doi.org/10.1186/1750-1172-9-87

Armstrong DD (1992) The neuropathology of the Rett syndrome. Brain Dev 14:S89-S98

Artuso R, Papa FT, Grillo E et al (2011) Investigation of modifier genes within copy number variations in Rett syndrome. J Hum Genet 56:508-515. https://doi.org/10.1038/jhg.2011.50

Baker AM, Batchelor DC, Thomas GB et al (2005) Central penetration and stability of $\mathrm{N}$-terminal tripeptide of insulin-like growth factor-I, glycine-proline-glutamate in adult rat. Neuropeptides 39:81-87. https://doi.org/10.1016/j.npep.2004.11.001

Ballas N, Lioy DT, Grunseich C, Mandel G (2009) Non-cell autonomous influence of MeCP2-deficient glia on neuronal dendritic morphology. Nat Neurosci 12:311-317. https://doi.org/10.1038/ nn. 2275

Barton-Davis ER, Cordier L, Shoturma DI et al (1999) Aminoglycoside antibiotics restore dystrophin function to skeletal muscles of mdx mice. J Clin Invest 104:375-381. https://doi.org/10.1172/ JCI7866

Berry-Kravis E, Levin R, Shah H et al (2015) Cholesterol levels in Fragile X syndrome. Am J Med Genet A 167:379-384. https:// doi.org/10.1002/ajmg.a.36850

Bhatnagar S, Zhu X, Ou J et al (2014) Genetic and pharmacological reactivation of the mammalian inactive $\mathrm{X}$ chromosome. Proc Natl 
Acad Sci 111:12591-12598. https://doi.org/10.1073/pnas.14136 20111

Bi X, Liao G (2010) Cholesterol in niemann-pick type C disease. Subcell Biochem 51:319-335. https://doi. org/10.1007/978-90-481-8622-8_11

Bianciardi L, Fichera M, Failla P et al (2016) MECP2 missense mutations outside the canonical MBD and TRD domains in males with intellectual disability. J Hum Genet 61:95-101. https://doi. org/10.1038/jhg. 2015.118

Bienvenu T, Carrié A, de Roux N et al (2000) MECP2 mutations account for most cases of typical forms of Rett syndrome. Hum Mol Genet 9:1377-1384

Bittolo T, Raminelli CA, Deiana C et al (2016) Pharmacological treatment with mirtazapine rescues cortical atrophy and respiratory deficits in MeCP2 null mice. Sci Rep. https://doi.org/10.1038/ srep19796

Bodda C, Tantra M, Mollajew R et al (2013) Mild overexpression of Mecp2 in mice causes a higher susceptibility toward seizures. Am J Pathol 183:195-210. https://doi.org/10.1016/j.ajpat h.2013.03.019

Braun S, Kottwitz D, Nuber UA (2012) Pharmacological interference with the glucocorticoid system influences symptoms and lifespan in a mouse model of Rett syndrome. Hum Mol Genet. https://doi. org/10.1093/hmg/ddr602

Brendel C, Belakhov V, Werner H et al (2011) Readthrough of nonsense mutations in Rett syndrome: evaluation of novel aminoglycosides and generation of a new mouse model. J Mol Med 89:389-398. https://doi.org/10.1007/s00109-010-0704-4

Brown K, Selfridge J, Lagger S et al (2016) The molecular basis of variable phenotypic severity among common missense mutations causing Rett syndrome. Hum Mol Genet 25:558-570. https://doi. org $/ 10.1093 / \mathrm{hmg} / \mathrm{ddv} 496$

Buchovecky CM, Turley SD, Brown HM et al (2013) A suppressor screen in Mecp2 mutant mice implicates cholesterol metabolism in Rett syndrome. Nat Genet 45:1013-1020. https://doi. org/10.1038/ng.2714

Carrette LLG, Wang C-Y, Wei C et al (2017) A mixed modality approach towards Xi reactivation for Rett syndrome and other X-linked disorders. Proc Natl Acad Sci. https://doi.org/10.1073/ pnas. 1715124115

Carrette LLG, Blum R, Ma W et al (2018) Tsix-Mecp2 female mouse model for Rett syndrome reveals that low-level MECP2 expression extends life and improves neuromotor function. Proc Natl Acad Sci. https://doi.org/10.1073/pnas.1800931115

Castro J, Garcia RI, Kwok S et al (2014) Functional recovery with recombinant human IGF1 treatment in a mouse model of Rett syndrome. Proc Natl Acad Sci 111:9941-9946. https://doi. org/10.1073/pnas.1311685111

Cedar H (1988) DNA methylation and gene activity. Cell 53:3-4

Chahrour M, Zoghbi HY (2007) The story of Rett syndrome: from clinic to neurobiology. Neuron 56:422-437

Chahrour M, Jung SYY, Shaw C et al (2008) MeCP2, a key contributor to neurological disease, activates and represses transcription. Science 320:1224-1229. https://doi.org/10.1126/science.1153252

Chandler SP, Guschin D, Landsberger N, Wolffe AP (1999) The methyl-CpG binding transcriptional repressor MeCP2 stably associates with nucleosomal DNA. Biochemistry 38:7008-7018. https://doi.org/10.1021/bi990224y

Chang Q, Khare G, Dani V et al (2006) The disease progression of Mecp 2 mutant mice is affected by the level of BDNF expression. Neuron 49:341-348. https://doi.org/10.1016/j.neuro n.2005.12.027

Chao H-TT, Chen H, Samaco RC et al (2010) Dysfunction in GABA signalling mediates autism-like stereotypies and Rett syndrome phenotypes. Nature 468:263-269. https://doi.org/10.1038/natur e09582
Chen RZ, Akbarian S, Tudor M, Jaenisch R (2001) Deficiency of methyl-CpG binding protein-2 in CNS neurons results in a Rett-like phenotype in mice. Nat Genet 27:327-331. https://doi. org/10.1038/85906

Chen WG, Chang Q, Lin Y et al (2003) Derepression of BDNF transcription involves calcium-dependent phosphorylation of MeCP2. Science 302:885-889. https://doi.org/10.1126/scien ce. 1086446

Chen Y, Yu J, Niu Y et al (2017) Modeling Rett syndrome ising TALEN-Edited MECP2 mutant cynomolgus monkeys. Cell 169:945-955.e10. https://doi.org/10.1016/j.cell.2017.04.035

Chin EWM, Lim WM, Ma D et al (2018) Choline rescues behavioural deficits in a mouse model of Rett syndrome by modulating neuronal plasticity. Mol Neurobiol 15:1-5

Cohen S, Gabel HW, Hemberg M et al (2011) Genome-wide activity-dependent $\mathrm{MeCP} 2$ phosphorylation regulates nervous system development and function. Neuron 72:72-85. https://doi. org/10.1016/j.neuron.2011.08.022

Collins AL, Levenson JM, Vilaythong AP et al (2004) Mild overexpression of $\mathrm{MeCP} 2$ causes a progressive neurological disorder in mice. Hum Mol Genet 13:2679-2689. https://doi.org/10.1093/ hmg/ddh 282

Conti E, Izaurralde E (2005) Nonsense-mediated mRNA decay: molecular insights and mechanistic variations across species. Curr Opin Cell Biol 17:316-325

Cuddapah VA, Pillai RB, Shekar KV et al (2014) Methyl-CpG-binding protein 2 (MECP2) mutation type is associated with disease severity in Rett syndrome. J Med Genet 51:152-158. https://doi. org/10.1136/jmedgenet-2013-102113

D’Ercole AJ, Ye P, Calikoglu AS, Gutierrez-Ospina G (1996) The role of the insulin-like growth factors in the central nervous system. Mol Neurobiol 13:227-255. https://doi.org/10.1007/BF02740625

De Felice C, Ciccoli L, Leoncini S et al (2009) Systemic oxidative stress in classic Rett syndrome. Free Radic Biol Med 47:440 448. https://doi.org/10.1016/j.freeradbiomed.2009.05.016

De Filippis B, Fabbri A, Simone D et al (2012) Modulation of RhoGTPases improves the behavioral phenotype and reverses astrocytic deficits in a mouse model of rett syndrome. Neuropsychopharmacology. https://doi.org/10.1038/npp.2011.301

De Filippis B, Ricceri L, Fuso A, Laviola G (2013) Neonatal exposure to low dose corticosterone persistently modulates hippocampal mineralocorticoid receptor expression and improves locomotor/exploratory behaviour in a mouse model of Rett syndrome. Neuropharmacology. https://doi.org/10.1016/j.neuropharm .2012.05.048

De Felice C, Della Ragione F, Signorini C et al (2014) Oxidative brain damage in Mecp2-mutant murine models of Rett syndrome. Neurobiol Dis 68:66-77. https://doi.org/10.1016/j.nbd.2014.04.006

De Filippis B, Nativio P, Fabbri A et al (2014) Pharmacological stimulation of the brain serotonin receptor 7 as a novel therapeutic approach for rett syndrome. Neuropsychopharmacology. https:// doi.org/10.1038/npp.2014.105

De Filippis B, Valenti D, Chiodi V et al (2015) Modulation of Rho GTPases rescues brain mitochondrial dysfunction, cognitive deficits and aberrant synaptic plasticity in female mice modeling Rett syndrome. Eur Neuropsychopharmacol. https://doi.org/10.1016/j. euroneuro.2015.03.012

Deacon RMJ, Glass L, Snape M et al (2015) NNZ-2566, a novel analog of (1-3) IGF-1, as a potential therapeutic agent for Fragile X syndrome. NeuroMol Med 17:71-82. https://doi.org/10.1007/ s12017-015-8341-2

Deaton AM, Webb S, Kerr ARW et al (2011) Cell type-specific DNA methylation at intragenic $\mathrm{CpG}$ islands in the immune system. Genome Res 21:1074-1086. https://doi.org/10.1101/gr.11870 3.110 
Deng V, Matagne V, Banine F et al (2007) FXYD1 is an MeCP2 target gene overexpressed in the brains of Rett syndrome patients and Mecp2-null mice. Hum Mol Genet 16:640-650. https://doi. org/10.1093/hmg/ddm007

Deogracias R, Yazdani M, Dekkers MP et al (2012) Fingolimod, a sphingosine-1 phosphate receptor modulator, increases BDNF levels and improves symptoms of a mouse model of Rett syndrome. Proc Natl Acad Sci 109:14230-14235

Derecki NC, Cronk JC, Lu Z et al (2012) Wild-type microglia arrest pathology in a mouse model of Rett syndrome. Nature. https:// doi.org/10.1038/nature10907

Dotti MT, Manneschi L, Malandrini A et al (1993) Mitochondrial dysfunction in Rett syndrome an ultrastructural and biochemical study. Brain Dev 15:103-106. https://doi.org/10.1016/03877604(93)90045-A

Du M, Liu X, Welch EM et al (2008) PTC124 is an orally bioavailable compound that promotes suppression of the human CFTRG542X nonsense allele in a CF mouse model. Proc Natl Acad Sci 105:2064-2069. https://doi.org/10.1073/pnas.0711795105

Ebert DH, Gabel HW, Robinson ND et al (2013) Activity-dependent phosphorylation of MeCP2 threonine 308 regulates interaction with NCoR. Nature 499:341-345. https://doi.org/10.1038/natur e12348

Eeg-Olofsson O, Al-Zuhair AG, Teebi AS, Al-Essa MM (1988) Abnormal mitochondria in the Rett syndrome. Brain Dev 10:260-262. https://doi.org/10.1016/S0387-7604(88)80010-X

Elefant C, Wigram T (2005) Learning ability in children with Rett syndrome. Brain Dev 27:S97-S101

El-Khoury R, Panayotis N, Matagne V et al (2014) GABA and glutamate pathways are spatially and developmentally affected in the brain of Mecp2-deficient mice. PLoS One. https://doi. org/10.1371/journal.pone.0092169

Engstrom LO (1985) The National Institutes of Health Small Business Innovation Research (SBIR) Program: opportunities for orphan drug development. Prog Clin Biol Res 192:25-30

Foust KD, Nurre E, Montgomery CL et al (2009) Intravascular AAV9 preferentially targets neonatal neurons and adult astrocytes. Nat Biotechnol 27:59-65. https://doi.org/10.1038/nbt.1515

Gadalla KKE, Bailey MES, Cobb SR (2011) MeCP2 and Rett syndrome: reversibility and potential avenues for therapy. Biochem J 439:1-14. https://doi.org/10.1042/BJ20110648

Gadalla KK, Bailey ME, Spike RC et al (2013) Improved survival and reduced phenotypic severity following AAV9/MECP2 gene transfer to neonatal and juvenile male Mecp2 knockout mice. Mol Ther 21:18-30. https://doi.org/10.1038/mt.2012.200

Gadalla KKE, Vudhironarit T, Hector RD et al (2017) Development of a novel AAV gene therapy cassette with improved safety features and efficacy in a mouse model of Rett syndrome. Mol TherMethods Clin Dev. https://doi.org/10.1016/j.omtm.2017.04.007

Gandaglia A, Brivio E, Carli S et al (2018) A novel Mecp2 Y120D knock-in model displays similar behavioral traits but distinct molecular features compared to the Mecp2-null mouse implying precision medicine for the treatment of Rett syndrome. Mol Neurobiol. https://doi.org/10.1007/s12035-018-1412-2

Garg SK, Lioy DT, Cheval H et al (2013) Systemic delivery of MeCP2 rescues behavioral and cellular deficits in female mouse models of Rett syndrome. J Neurosci 33:13612-13620. https://doi. org/10.1523/JNEUROSCI.1854-13.2013

Geisler A, Fechner H (2016) MicroRNA-regulated viral vectors for gene therapy. World J Exp Med. https://doi.org/10.5493/wjem. v6.i2.37

Goffin D, Allen M, Zhang L et al (2011) Rett syndrome mutation MeCP2 T158A disrupts DNA binding, protein stability and ERP responses. Nat Neurosci 15:274-283. https://doi.org/10.1038/ nn.2997
Goffin D, Zhou Z (Joe) (2012) The neural circuit basis of Rett syndrome. Front Biol (Beijing). 7:428-435

Gogliotti RG, Senter RK, Rook JM et al (2016) MGlu5positive allosteric modulation normalizes synaptic plasticity defects and motor phenotypes in a mouse model of Rett syndrome. Hum Mol Genet doi. https://doi.org/10.1093/hmg/ddw074

Gogliotti RG, Senter RK, Fisher NM et al (2017) MGlu7potentiation rescues cognitive, social, and respiratory phenotypes in a mouse model of Rett syndrome. Sci Transl Med. https://doi.org/10.1126/ scitranslmed.aai7459

Gold WA, Williamson SL, Kaur S et al (2014) Mitochondrial dysfunction in the skeletal muscle of a mouse model of Rett syndrome (RTT): implications for the disease phenotype. Mitochondrion 15:10-17. https://doi.org/10.1016/j.mito.2014.02.012

Gonçalves MAFV (2005) Adeno-associated virus: from defective virus to effective vector. Virol J 2:43

Gopinath C, Nathar T, Ghosh A et al (2015) Contemporary animal models for human gene therapy applications. Curr Gene Ther. https://doi.org/10.2174/1566523215666150929110424

Großer E, Hirt U, Janc OA et al (2012) Oxidative burden and mitochondrial dysfunction in a mouse model of Rett syndrome. Neurobiol Dis 48:102-114. https://doi.org/10.1016/j.nbd.2012.06.007

Guerin K, Gregory-Evans CY, Hodges MD et al (2008) Systemic aminoglycoside treatment in rodent models of retinitis pigmentosa. Exp Eye Res 87:197-207. https://doi.org/10.1016/j. exer.2008.05.016

Guy J, Hendrich B, Holmes M et al (2001) A mouse Mecp2-null mutation causes neurological symptoms that mimic Rett syndrome. Nat Genet 27:322-326. https://doi.org/10.1038/85899

Guy J, Gan J, Selfridge J et al (2007) Reversal of neurological defects in a mouse model of Rett syndrome. Science 315:1143-1147. https://doi.org/10.1126/science.1138389

Guy J, Cheval H, Selfridge J, Bird A (2011) The role of MeCP2 in the brain. Annu Rev Cell Dev Biol 27:631-652. https://doi. org/10.1146/annurev-cellbio-092910-154121

Haas RH (1988) The history and challenge of Rett syndrome. J Child Neurol 3:S3-S5. https://doi.org/10.1177/088307388800300102

Haas RH, Nasirian F, Hua X et al (1995) Oxidative metabolism in Rett syndrome: 2-biochemical and molecular studies. Neuropediatrics 26:95-99. https://doi.org/10.1055/s-2007-979735

Haas RH, Dixon SD, Sartoris DJ, Hannessy MJ (1997) Osteopenia in Rett syndrome. J Pediatr 131:771-774. https://doi.org/10.1016/ S0022-3476(97)70113-6

Hagberg B (2002) Clinical manifestations and stages of Rett syndrome. Ment Retard Dev Disabil Res Rev 8:61-65. https://doi. org/10.1002/mrdd.10020

Hagberg B, Witt-Engerström I (1986) Rett syndrome: a suggested staging system for describing impairment profile with increasing age towards adolescence. Am J Med Genet 1:47-59

Hagberg B, Aicardi J, Dias K, Ramos O (1983) A progressive syndrome of autism, dementia, ataxia, and loss of purposeful hand use in girls: Rett's syndrome: report of 35 cases. Ann Neurol 14:471-479. https://doi.org/10.1002/ana.410140412

Hao S, Tang B, Wu Z et al (2015) Forniceal deep brain stimulation rescues hippocampal memory in Rett syndrome mice. Nature. https://doi.org/10.1038/nature15694

Hara M, Takahashi T, Mitsumasu C et al (2015) Disturbance of cardiac gene expression and cardiomyocyte structure predisposes Mecp2-null mice to arrhythmias. Sci Rep 5:1-17. https://doi. org/10.1038/srep11204

Hendrich B, Tweedie S (2003) The methyl-CpG binding domain and the evolving role of DNA methylation in animals. Trends Genet 19:269-277

Hinderer C, Katz N, Buza EL et al (2018) Severe toxicity in nonhuman primates and piglets following high-dose intravenous 
administration of an AAV vector expressing human SMN. Hum Gene Ther. https://doi.org/10.1089/hum.2018.015

Ishii T, Makita Y, Ogawa A et al (2001) The role of different X-inactivation pattern on the variable clinical phenotype with Rett syndrome. In: Brain and development. Elsevier, Amsterdam, pp 161-164

Itoh M, Ide S, Takashima S et al (2007) Methyl CpG-binding protein 2 (a mutation of which causes Rett syndrome) directly regulates insulin-like growth factor binding protein 3 in mouse and human brains. J Neuropathol Exp Neurol 66:117-123. https:// doi.org/10.1097/nen.0b013e3180302078

Itoh M, Tahimic CGT, Ide S et al (2012) Methyl CpG-binding protein isoform MeCP2-e2 is dispensable for Rett syndrome phenotypes but essential for embryo viability and placenta development. J Biol Chem 287:13859-13867. https://doi.org/10.1074/jbc. M111.309864

Janc OA, Hüser MA, Dietrich K et al (2016) Systemic radical scavenger treatment of a mouse model of Rett syndrome: merits and limitations of the vitamin E derivative trolox. Front Cell Neurosci. https://doi.org/10.3389/fncel.2016.00266

Jentarra GM, Olfers SL, Rice SG et al (2010) Abnormalities of cell packing density and dendritic complexity in the MeCP2 A140V mouse model of Rett syndrome/X-linked mental retardation. BMC Neurosci 11:19. https://doi.org/10.1186/1471-2202-11-19

Johnson RA, Lam M, Punzo AM et al (2012) 7,8-dihydroxyflavone exhibits therapeutic efficacy in a mouse model of Rett syndrome. J Appl Physiol. https://doi.org/10.1152/japplphysiol.01361.2011

Justice MJ, Buchovecky CM, Kyle SM, Djukic A (2013) A role for metabolism in Rett syndrome pathogenesis: new clinical findings and potential treatment targets. Rare Dis 1:e27265. https://doi. org/10.4161/rdis.27265

Katz DM, Menniti FS, Mather RJ (2016) N-methyl-D-aspartate receptors, ketamine, and Rett syndrome: something special on the road to treatments? Biol Psychiatry 79:710-712

Keeling KM, Xue X, Gunn G, Bedwell DM (2014) Therapeutics based on stop codon readthrough. Annu Rev Genom Hum Genet 15:371-394. https://doi.org/10.1146/annurev-genom-09121 $2-153527$

Kerem E, Konstan MW, De Boeck K et al (2014) Ataluren for the treatment of nonsense-mutation cystic fibrosis: a randomised, double-blind, placebo-controlled phase 3 trial. Lancet Respir Med 2:539-547. https://doi.org/10.1016/S2213-2600(14)70100-6

Khwaja OS, Ho E, Barnes KV et al (2014) Safety, pharmacokinetics, and preliminary assessment of efficacy of mecasermin (recombinant human IGF-1) for the treatment of Rett syndrome. Proc Natl Acad Sci 111:4596-4601. https://doi.org/10.1073/pnas.13111 41111

Kishi N, Macklis JD (2004) MECP2 is progressively expressed in postmigratory neurons and is involved in neuronal maturation rather than cell fate decisions. Mol Cell Neurosci 27:306-321. https:// doi.org/10.1016/j.mcn.2004.07.006

Knudsen GPS, Neilson TCS, Pedersen J et al (2006) Increased skewing of $\mathrm{X}$ chromosome inactivation in Rett syndrome patients and their mothers. Eur J Hum Genet 14:1189-1194. https://doi. org/10.1038/sj.ejhg.5201682

Koerner MV, FitzPatrick L, Selfridge J et al (2018) Toxicity of overexpressed MeCP2 is independent of HDAC3 activity. Genes Dev 32:1514-1524

Kondo M, Gray LJ, Pelka GJ et al (2008) Environmental enrichment ameliorates a motor coordination deficit in a mouse model of Rett syndrome-Mecp2 gene dosage effects and BDNF expression. Eur J Neurosci. https://doi.org/10.1111/j.1460-9568.2008.06305 . $\mathrm{x}$

Kondo MA, Gray LJ, Pelka GJ et al (2016) Affective dysfunction in a mouse model of Rett syndrome: therapeutic effects of environmental stimulation and physical activity. Dev Neurobiol. https://doi.org/10.1002/dneu.22308

Kriaucionis S, Paterson A, Curtis J et al (2006) Gene expression analysis exposes mitochondrial abnormalities in a mouse model of Rett syndrome. Mol Cell Biol 26:5033-5042. https://doi. org/10.1128/MCB.01665-05

Krishnan N, Krishnan K, Connors CR et al (2015) PTP1B inhibition suggests a therapeutic strategy for Rett syndrome. J Clin Invest 125:3163-3177. https://doi.org/10.1172/JCI80323

Kron M, Howell CJ, Adams IT et al (2012) Brain activity mapping in Mecp2 mutant mice reveals functional deficits in forebrain circuits, including key nodes in the default mode network, that are reversed with ketamine treatment. J Neurosci 32:13860-13872. https://doi.org/10.1523/JNEUROSCI.2159-12.2012

Kron M, Lang M, Adams IT et al (2014) A BDNF loop-domain mimetic acutely reverses spontaneous apneas and respiratory abnormalities during behavioral arousal in a mouse model of Rett syndrome. Dis Model Mech 7:1047-1055. https://doi. org/10.1242/dmm.016030

Kumar A, Jaryal A, Gulati S et al (2017) Cardiovascular autonomic dysfunction in children and adolescents with Rett syndrome. Pediatr Neurol 70:61-66. https://doi.org/10.1016/j.pediatrneu rol.2017.01.010

Kumaran N, Smith AJ, Michaelides M et al (2018) Gene therapy for leber congenital amaurosis. Expert Rev Ophthalmol 13:11-15

Kuzmiak HA, Maquat LE (2006) Applying nonsense-mediated mRNA decay research to the clinic: progress and challenges. Trends Mol Med 12:306-316

Kyle SM, Saha PK, Brown HM et al (2016) MeCP2 co-ordinates liver lipid metabolism with the NCoR1/HDAC3 corepressor complex. Hum Mol Genet 25:3029-3041. https://doi.org/10.1093/ $\mathrm{hmg} / \mathrm{ddw} 156$

Kyle SM, Vashi N, Justice MJ (2018) Rett syndrome: a neurological disorder with metabolic components. Open Biol 8:170216. https ://doi.org/10.1098/rsob.170216

Lalonde R, Strazielle C (2011) Brain regions and genes affecting limbclasping responses. Brain Res. Rev 67:252-259

Laurvick CL, de Klerk N, Bower C et al (2006) Rett syndrome in Australia: a review of the epidemiology. J Pediatr 148:347-352. https://doi.org/10.1016/j.jpeds.2005.10.037

Lawson-Yuen A, Liu D, Han L et al (2007) Ube3a mRNA and protein expression are not decreased in Mecp2R168X mutant mice. Brain Res 1180:1-6. https://doi.org/10.1016/j.brainres.2007.08.039

Leoncini S, De Felice C, Signorini C et al (2011) Oxidative stress in Rett syndrome: natural history, genotype, and variants. Redox Rep 16:145-153. https://doi.org/10.1179/1351000211Y.00000 00004

Levitt ES, Hunnicutt BJ, Knopp SJ et al (2013) A selective 5-HT receptor agonist improves respiration in a mouse model of Rett syndrome. J Appl Physiol. https://doi.org/10.1152/japplphysi ol.00889.2013

Lewis JD, Meehan RR, Henzel WJ et al (1992) Purification, sequence, and cellular localization of a novel chromosomal protein that binds to Methylated DNA. Cell 69:905-914. https://doi. org/10.1016/0092-8674(92)90610-O

Li W, Bellot-Saez A, Phillips ML et al (2017) A small-molecule TrkB ligand restores hippocampal synaptic plasticity and object location memory in Rett syndrome mice. Dis Model Mech. https:// doi.org/10.1242/dmm.029959

Ligsay A, Hagerman RJ (2016) Review of targeted treatments in fragile X syndrome. Intractable Rare Dis Res 5:158-167

Linde L, Boelz S, Nissim-Rafinia M et al (2007) Nonsense-mediated mRNA decay affects nonsense transcript levels and governs response of cystic fibrosis patients to gentamicin. J Clin Invest. https://doi.org/10.1172/JCI28523 
Lioy DT, Garg SK, Monaghan CE et al (2011) A role for glia in the progression of Rett's syndrome. Nature 475:497-500. https://doi. org/10.1038/nature 10214

Liu K, Zhang L, Chen J et al (2013) Association of MeCP2 (rs2075596, rs2239464) genetic polymorphisms with systemic lupus erythematosus: a meta-analysis. Lupus 22:908-918. https://doi. org/10.1177/0961203313496340

Liu H, Chen Y, Niu Y et al (2014) TALEN-mediated gene mutagenesis in rhesus and cynomolgus monkeys. Cell Stem Cell 14:323-328. https://doi.org/10.1016/j.stem.2014.01.018

Lonetti G, Angelucci A, Morando L et al (2010) Early environmental enrichment moderates the behavioral and synaptic phenotype of MeCP2 Null mice. Biol Psychiatry. https://doi.org/10.1016/j. biopsych.2009.12.022

Lyst MJ, Bird A (2015) Rett syndrome: a complex disorder with simple roots. Nat Rev Genet 16:261-275. https://doi.org/10.1038/ nrg3897

Lyst MJ, Ekiert R, Ebert DH et al (2013) Rett syndrome mutations abolish the interaction of MeCP2 with the NCoR/SMRT corepressor. Nat Neurosci 16:898-902. https://doi.org/10.1038/ nn.3434

Mancini J, Dubus JC, Jouve E et al (2018) Effect of desipramine on patients with breathing disorders in RETT syndrome. Ann Clin Transl Neurol. https://doi.org/10.1002/acn3.468

Mantis JG, Fritz CL, Marsh J et al (2009) Improvement in motor and exploratory behavior in Rett syndrome mice with restricted ketogenic and standard diets. Epilepsy Behav. https://doi. org/10.1016/j.yebeh.2009.02.038

McCarty DM, Monahan PE, Samulski RJ (2001) Self-complementary recombinant adeno-associated virus (scAAV) vectors promote efficient transduction independently of DNA synthesis. Gene Ther 8:1248-1254. https://doi.org/10.1038/sj.gt.3301514

McCauley MD, Wang T, Mike E et al (2011) Pathogenesis of lethal cardiac arrhythmias in Mecp2 mutant mice: implication for therapy in Rett syndrome. Sci Transl Med 3:113ra125-113ra125. https:// doi.org/10.1126/scitranslmed.3002982

McDonald CM, Campbell C, Torricelli RE et al (2017) Ataluren in patients with nonsense mutation Duchenne muscular dystrophy (ACT DMD): a multicentre, randomised, double-blind, placebocontrolled, phase 3 trial. Lancet 390:1489-1498. https://doi. org/10.1016/S0140-6736(17)31611-2

Mellios N, Woodson J, Garcia RI et al (2014) $\beta 2$-Adrenergic receptor agonist ameliorates phenotypes and corrects microRNA-mediated IGF1 deficits in a mouse model of Rett syndrome. Proc Natl Acad Sci. https://doi.org/10.1073/pnas.1309426111

Minkovsky A, Sahakyan A, Bonora G et al (2015) A high-throughput screen of inactive $X$ chromosome reactivation identifies the enhancement of DNA demethylation by 5-aza-2'-dC upon inhibition of ribonucleotide reductase. Epigenet Chromatin. https:// doi.org/10.1186/s13072-015-0034-4

Mochel F, DeLonlay P, Touati G et al (2005) Pyruvate carboxylase deficiency: Clinical and biochemical response to anaplerotic diet therapy. Mol Genet Metab 84:305-312. https://doi.org/10.1016/j. ymgme.2004.09.007

Modi ME, Sahin M (2018) The way forward for mechanism-based therapeutics in genetically defined neurodevelopmental disorders. Clin Pharmacol Ther 104:603-06

Moretti P (2006) Learning and memory and synaptic plasticity are impaired in a mouse model of Rett syndrome. J Neurosci. https ://doi.org/10.1523/JNEUROSCI.2623-05.2006

Morgan P, Brown DG, Lennard S et al (2018) Impact of a five-dimensional framework on R\&D productivity at AstraZeneca. Nat Rev Drug Discov 17:167

Motil KJ, Caeg E, Barrish JO et al (2012) Gastrointestinal and nutritional problems occur frequently throughout life in girls and women with Rett syndrome. J Pediatr Gastroenterol Nutr 55:292298. https://doi.org/10.1097/MPG.0b013e31824b6159

Mount RH, Charman T, Hastings RP et al (2002) The Rett syndrome behaviour questionnaire (RSBQ): refining the behavioural phenotype of Rett syndrome. J Child Psychol Psychiatry Allied Discip. https://doi.org/10.1111/1469-7610.00236

Na ES, De Jesús-Cortés H, Martinez-Rivera A et al (2017) D-cycloserine improves synaptic transmission in an animal mode of Rett syndrome. PLoS ONE. https://doi.org/10.1371/journ al.pone. 0183026

Nag N, Berger-Sweeney JE (2007) Postnatal dietary choline supplementation alters behavior in a mouse model of Rett syndrome. Neurobiol Dis. https://doi.org/10.1016/j.nbd.2007.02.003

Nag N, Moriuchi JM, Peitzman CGK et al (2009) Environmental enrichment alters locomotor behaviour and ventricular volume in Mecp21lox mice. Behav Brain Res. https://doi.org/10.1016/j. bbr.2008.07.008

Nagel-Wolfrum K, Möller F, Penner I et al (2016) Targeting nonsense mutations in diseases with translational read-through-inducing drugs (TRIDs). BioDrugs 30:49-74. https://doi.org/10.1007/ s40259-016-0157-6

Nagy E, Maquat LE (1998) A rule for termination-codon position within intron-containing genes: when nonsense affects RNA abundance. Trends Biochem Sci 6:198-199

Nan X, Campoy FJ, Bird A (1997) MeCP2 is a transcriptional repressor with abundant binding sites in genomic chromatin. Cell $88: 471-481$

Nance E, Kambhampati SP, Smith ES et al (2017) Dendrimer-mediated delivery of $\mathrm{N}$-acetyl cysteine to microglia in a mouse model of Rett syndrome. J Neuroinflamm. https://doi.org/10.1186/s1297 4-017-1004-5

Neul JL, Fang P, Barrish J et al (2008) Specific mutations in methylCpG-binding protein 2 confer different severity in Rett syndrome. Neurology 70:1313-1321. https://doi.org/10.1212/01.wnl.00002 91011.54508.aa

Nguyen LS, Wilkinson MF, Gecz J (2014) Nonsense-mediated mRNA decay: inter-individual variability and human disease. Neurosci Biobehav Rev 46:175-186

O'Leary HM, Kaufmann WE, Barnes KV et al (2018) Placebo-controlled crossover assessment of mecasermin for the treatment of Rett syndrome. Ann Clin Transl Neurol 5:323-332. https://doi. org/10.1002/acn3.533

Ogier M, Wang H, Hong E et al (2007) Brain-derived neurotrophic factor expression and respiratory function improve after ampakine treatment in a mouse model of Rett syndrome. J Neurosci. https ://doi.org/10.1523/JNEUROSCI.1869-07.2007

Ohno K, Saito Y, Ueda R et al (2016) Effect of serotonin 1A agonists and selective serotonin reuptake inhibitors on behavioral and nighttime respiratory symptoms in Rett syndrome. Pediatr Neurol. https://doi.org/10.1016/j.pediatrneurol.2016.03.016

Orefice LLL, Zimmerman ALL, Chirila AMM et al (2016) Peripheral mechanosensory neuron dysfunction underlies tactile and behavioral deficits in mouse models of ASDs. Cell. https://doi. org/10.1016/j.cell.2016.05.033

Panighini A, Duranti E, Santini F et al (2013) Vascular dysfunction in a mouse model of Rett syndrome and effects of curcumin treatment. PLoS ONE. https://doi.org/10.1371/journal.pone.0064863

Park MJ, Aja S, Li Q et al (2014) Anaplerotic triheptanoin diet enhances mitochondrial substrate use to remodel the metabolome and improve lifespan, motor function, and sociability in MeCP2-null mice. PLoS ONE. https://doi.org/10.1371/journ al.pone. 0109527

Paterson DS, Thompson EG, Belliveau RA et al (2005) Serotonin transporter abnormality in the dorsal motor nucleus of the vagus in rett syndrome: potential implications for clinical 
autonomic dysfunction. J Neuropathol Exp Neurol 64:10181027. https://doi.org/10.1097/01.jnen.0000187054.59018.f2

Patrizi A, Picard N, Simon AJ et al (2016) Chronic administration of the N-methyl-D-aspartate receptor antagonist ketamine improves Rett syndrome phenotype. Biol Psychiatry 79:755764. https://doi.org/10.1016/j.biopsych.2015.08.018

Pelka GJ, Watson CM, Radziewic T et al (2006) Mecp2 deficiency is associated with learning and cognitive deficits and altered gene activity in the hippocampal region of mice. Brain. https ://doi.org/10.1093/brain/awl022

Pitcher MR, Ward CS, Arvide EM et al (2013) Insulinotropic treatments exacerbate metabolic syndrome in mice lacking MeCP2 function. Hum Mol Genet. https://doi.org/10.1093/hmg/ddt111

Pitcher MR, Herrera JA, Buffington SA et al (2015) Rett syndrome like phenotypes in the R255X Mecp2 mutant mouse are rescued by MECP2 transgene. Hum Mol Genet 24:2662-2672. https://doi.org/10.1093/hmg/ddv030

Pizzo L, Jensen M, Polyak A et al (2018) Rare variants in the genetic background modulate cognitive and developmental phenotypes in individuals carrying disease-associated variants. Genet Med. https://doi.org/10.1038/s41436-018-0266-3

Popescu AC, Sidorova E, Zhang G, Eubanks JH (2010) Aminoglycoside-mediated partial suppression of MECP2 nonsense mutations responsible for Rett syndrome in vitro. J Neurosci Res 88:2316-2324. https://doi.org/10.1002/jnr.22409

Puglielli L, Tanzi RE, Kovacs DM (2003) Alzheimer's disease: the cholesterol connection. Nat Neurosci 6:345-351. https://doi. org/10.1038/nn0403-345

Ramirez JM, Ward CS, Neul JL (2013) Breathing challenges in Rett Syndrome: lessons learned from humans and animal models. Respir Physiol Neurobiol 189:280-287

Renthal W, Boxer LD, Hrvatin S et al (2018) Characterization of human mosaic Rett syndrome brain tissue by single-nucleus RNA sequencing. Nat Neurosci 21:1670-1679. https://doi. org/10.1038/s41593-018-0270-6

Rett A (1966) On a unusual brain atrophy syndrome in hyperammonemia in childhood. Wien Med Wochenschr 1946:723-726

Ricceri L, De Filippis B, Fuso A, Laviola G (2011) Cholinergic hypofunction in MeCP2-308 mice: beneficial neurobehavioural effects of neonatal choline supplementation. Behav Brain Res. https://doi.org/10.1016/j.bbr.2011.03.051

Roe CR, Sweetman L, Roe DS et al (2002) Treatment of cardiomyopathy and rhabdomyolysis in long-chain fat oxidation disorders using an anaplerotic odd-chain triglyceride. J Clin Investig 110:259-269. https://doi.org/10.1172/JCI0215311

Roux JC, Dura E, Moncla A et al (2007) Treatment with desipramine improves breathing and survival in a mouse model for Rett syndrome. Eur J Neurosci. https://doi.org/10.111 1/j.1460-9568.2007.05466.x

Samaco RC, Fryer JD, Ren J et al (2008) A partial loss of function allele of Methyl-CpG-binding protein 2 predicts a human neurodevelopmental syndrome. Hum Mol Genet 17:1718-1727. https://doi.org/10.1093/hmg/ddn062

Samaco RC, Mandel-Brehm C, McGraw CM et al (2012) Crh and Oprm1 mediate anxiety-related behavior and social approach in a mouse model of MECP2 duplication syndrome. Nat Genet. https://doi.org/10.1038/ng.1066

Santos M, Summavielle T, Teixeira-Castro A et al (2010) Monoamine deficits in the brain of methyl-CpG binding protein 2 null mice suggest the involvement of the cerebral cortex in early stages of Rett syndrome. Neuroscience. https://doi. org/10.1016/j.neuroscience.2010.07.010

Schaevitz LR, Nicolai R, Lopez CM et al (2012) Acetyl-L-carnitine improves behavior and dendritic morphology in a mouse model of Rett syndrome. PLoS ONE. https://doi.org/10.1371/journ al.pone.0051586
Schaevitz LR, Gómez NB, Zhen DP, Berger-Sweeney JE (2013) MeCP2 R168X male and female mutant mice exhibit Rett-like behavioral deficits. Genes, Brain Behav. https://doi.org/10.1111/ gbb. 12070

Schmid DA, Yang T, Ogier M et al (2012) A TrkB small molecule partial agonist rescues TrkB phosphorylation deficits and improves respiratory function in a mouse model of Rett syndrome. J Neurosci. https://doi.org/10.1523/JNEUROSCI.0865-11.2012

Schon EA, Manfredi G (2003) Neuronal degeneration and mitochondrial dysfunction. J Clin Investig 111:303-312

Segatto M, Trapani L, Di Tunno I et al (2014) Cholesterol metabolism is altered in Rett syndrome: a study on plasma and primary cultured fibroblasts derived from patients. PLoS ONE 9:e104834. https://doi.org/10.1371/journal.pone.0104834

Shahbazian MD, Young JI, Yuva-Paylor LA et al (2002a) Mice with truncated $\mathrm{MeCP} 2$ recapitulate many Rett syndrome features and display hyperacetylation of histone H3. Neuron 35:243-254. https://doi.org/10.1016/S0896-6273(02)00768-7

Shahbazian MD, Antalffy B, Armstrong DL, Zoghbi HY (2002b) Insight into Rett syndrome: MeCP2 levels display tissue- and cell-specific differences and correlate with neuronal maturation. Hum Mol Genet 11:115-124. https://doi.org/10.1093/ $\mathrm{hmg} / 11.2 .115$

Shapiro JR, Bibat G, Hiremath G et al (2010) Bone mass in Rett syndrome: association with clinical parameters and MECP2 mutations. Pediatr Res 68:446-451. https://doi.org/10.1203/ PDR.0b013e3181f2edd2

Shulyakova N, Andreazza AC, Mills LR, Eubanks JH (2017) Mitochondrial dysfunction in the pathogenesis of Rett syndrome: implications for mitochondria-targeted therapies. Front Cell Neurosci. https://doi.org/10.3389/fncel.2017.00058

Sinnett SE, Hector RD, Gadalla KKE et al (2017) Improved MECP2 gene therapy extends the survival of MeCP2-null mice without apparent Toxicity after intracisternal delivery. Mol TherMethods Clin Dev 5:106-115. https://doi.org/10.1016/j. omtm.2017.04.006

Skene PJ, Illingworth RS, Webb S et al (2010) Neuronal MeCP2 is expressed at near histone-octamer levels and globally alters the chromatin state. Mol Cell 37:457-468. https://doi.org/10.1016/j. molcel.2010.01.030

Sripathy S, Leko V, Adrianse RL et al (2017) Screen for reactivation of MeCP2 on the inactive X chromosome identifies the BMP/ TGF- $\beta$ superfamily as a regulator of XIST expression. Proc Natl Acad Sci 114:1619-1624. https://doi.org/10.1073/pnas.16213 56114

Szczesna K, De La Caridad O, Petazzi P et al (2014) Improvement of the rett syndrome phenotype in a mecp2 mouse model upon treatment with levodopa and a dopa-decarboxylase inhibitor. Neuropsychopharmacology. https://doi.org/10.1038/npp.2014.136

Tao J, Hu K, Chang Q et al (2009) Phosphorylation of MeCP2 at Serine 80 regulates its chromatin association and neurological function. Proc Natl Acad Sci 106:4882-4887. https://doi.org/10.1073/ pnas.0811648106

Tao J, Wu H, Coronado AA et al (2016) Negative allosteric modulation of mGluR5 partially corrects pathophysiology in a mouse model of Rett syndrome. J Neurosci. https://doi.org/10.1523/JNEUR OSCI.0672-16.2016

Tate P, Skarnes W, Bird A (1996) The methyl-CpG binding protein $\mathrm{MeCP} 2$ is essential for embryonic development in the mouse. Nat Genet 12:205-208. https://doi.org/10.1038/ng0296-205

Tillotson R, Selfridge J, Koerner MV et al (2017) Radically truncated $\mathrm{MeCP} 2$ rescues Rett syndrome-like neurological defects. Nature 550:398-401. https://doi.org/10.1038/nature24058

Tint GS, Irons M, Elias ER et al (1994) Defective cholesterol biosynthesis associated with the Smith-Lemli-Opitz syndrome. N 
Engl J Med 330:107-113. https://doi.org/10.1056/NEJM199401 133300205

Toward MA, Abdala AP, Knopp SJ et al (2013) Increasing brain serotonin corrects $\mathrm{CO}_{2}$ chemosensitivity in methyl-CpG-binding protein 2 (Mecp2)-deficient mice. Exp Physiol. https://doi. org/10.1113/expphysiol.2012.069872

Tropea D, Giacometti E, Wilson NR et al (2009) Partial reversal of Rett syndrome-like symptoms in MeCP2 mutant mice. Proc Natl Acad Sci USA 106:2029-2034. https://doi.org/10.1073/ pnas.0812394106

Vacca M, Della Ragione F, Scalabrì F, D'Esposito M (2016) X inactivation and reactivation in X-linked diseases. Semin Cell Dev Biol 56:78-87

Van Esch H, Bauters M, Ignatius J et al (2005) Duplication of the MECP2 region is a frequent cause of severe mental retardation and progressive neurological symptoms in males. Am J Hum Genet 77:442-453

Viemari J-C (2005) Mecp2 deficiency disrupts norepinephrine and respiratory systems in mice. J Neurosci 25:11521-11530. https ://doi.org/10.1523/JNEUROSCI.4373-05.2005

Vigli D, Cosentino L, Raggi C et al (2018) Chronic treatment with the phytocannabinoid Cannabidivarin (CBDV) rescues behavioural alterations and brain atrophy in a mouse model of Rett syndrome. Neuropharmacology. https://doi.org/10.1016/j.neuro pharm.2018.07.029

Ward CS, Huang TW, Herrera JA et al (2016) Loss of MeCP2 causes urological dysfunction and contributes to death by kidney failure in mouse models of rett syndrome. PLoS ONE. https://doi. org/10.1371/journal.pone. 0165550

Wegener E, Brendel C, Fischer A et al (2014) Characterization of the MeCP2R168X knockin mouse model for Rett syndrome. PLoS ONE 9:e115444. https://doi.org/10.1371/journal.pone.0115444
Wenk GL (1995) Alterations in dopaminergic function in Rett syndrome. Neuropediatrics 26:123-125. https://doi. org/10.1055/s-2007-979741

Wu Y, Zhong W, Cui N et al (2016) Characterization of Rett syndromelike phenotypes in Mecp2-knockout rats. J Neurodev Disord 8:23. https://doi.org/10.1186/s11689-016-9156-7

Xi CY, Lu Y, Tan YH et al (2011) Analysis of MECP2 gene copy number in boys with autism. J Child Neurol 26:570-573. https ://doi.org/10.1177/0883073810387138

Yasui DH, Gonzales ML, Aflatooni JO et al (2014) Mice with an isoform-ablating Mecp2 exon 1 mutation recapitulate the neurologic deficits of Rett syndrome. Hum Mol Genet 23:2447-2458. https ://doi.org/10.1093/hmg/ddt640

Young D, Nagarajan L, de Klerk N et al (2007) Sleep problems in Rett syndrome. Brain Dev 29:609-616. https://doi.org/10.1016/j.brain dev.2007.04.001

Zanella S, Mebarek S, Lajard AM et al (2008) Oral treatment with desipramine improves breathing and life span in Rett syndrome mouse model. Respir Physiol Neurobiol. https://doi. org/10.1016/j.resp.2007.08.009

Zhang Q, Zhao Y, Bao X et al (2017) Familial cases and male cases with MECP2 mutations. Am J Med Genet B. https://doi. org/10.1002/ajmg.b.32534

Zhong W, Johnson CM, Wu Y et al (2016) Effects of early-life exposure to THIP on phenotype development in a mouse model of Rett syndrome. J Neurodev Disord. https://doi.org/10.1186/s1168 9-016-9169-2

Publisher's Note Springer Nature remains neutral with regard to jurisdictional claims in published maps and institutional affiliations. 